\title{
Biometric analysis and aversive conditioning of black bears in southern West Virginia
}

Harley Wayne Weaver

West Virginia University

Follow this and additional works at: https://researchrepository.wvu.edu/etd

\section{Recommended Citation}

Weaver, Harley Wayne, "Biometric analysis and aversive conditioning of black bears in southern West Virginia" (2004). Graduate Theses, Dissertations, and Problem Reports. 2056.

https://researchrepository.wvu.edu/etd/2056

This Thesis is protected by copyright and/or related rights. It has been brought to you by the The Research Repository @ WVU with permission from the rights-holder(s). You are free to use this Thesis in any way that is permitted by the copyright and related rights legislation that applies to your use. For other uses you must obtain permission from the rights-holder(s) directly, unless additional rights are indicated by a Creative Commons license in the record and/ or on the work itself. This Thesis has been accepted for inclusion in WVU Graduate Theses, Dissertations, and Problem Reports collection by an authorized administrator of The Research Repository @ WVU. For more information, please contact researchrepository@mail.wvu.edu. 


\title{
Biometric Analysis and Aversive Conditioning of Black Bears in Southern West Virginia
}

\author{
Harley Wayne Weaver
}

\author{
Thesis submitted to the \\ Davis College of Agriculture, Forestry, and Consumer Sciences \\ at West Virginia University \\ in partial fulfillment of the requirement for the degree of
}

\section{Master of Science \\ In Wildlife and Fisheries Resource Management}

\author{
Dr. James T. Anderson, Co-Chair \\ Dr. John W. Edwards, Co-Chair \\ Thomas L. Dotson
}

Division of Forestry
Morgantown, West Virginia
2004

Keywords: Aversive Conditioning, Black Bear, Nuisance, West Virginia Copyright 2004, Harley Wayne Weaver 


\title{
ABSTRACT \\ Biometric Analysis and Aversive Conditioning of Black Bears in Southern West Virginia
}

\author{
Harley Wayne Weaver
}

During 2003, 11 male and 1 female black bear (Ursus americanus) were captured and fitted with radio collars. Individuals were randomly assigned to receive either treatment $(n=6)$ or control $(n=6)$. Upon release, treatment individuals received a conditional regimen comprised of rubber buckshot to the flank and a succession of shell crackers. Physical and auditory conditioning techniques we used did not appear to be an effective means of reducing repeat nuisance behavior.

West Virginia Division of Natural Resources (WVDNR) captured 179 (151 males, 28 females) nuisance and 156 (77 males, 79 females) non-nuisance individuals from 1996 to 2003. Initial age of capture was greater for nuisance $(n=133, \bar{x}=3.77 \mathrm{yr}, \mathrm{SE}=0.21)$ than non-nuisance $(n=105, \bar{x}=3.39 \mathrm{yr}, \mathrm{SE}=0.26)$ bears $\left(F_{1,234}=19.28, P<0.001\right)$. Mean litter size was similar for nuisance $(n=19, \bar{x}=3.16$ cubs, $\mathrm{SD}=0.93)$ and nonnuisance $(n=37, \bar{x}=2.65$ cubs, $\mathrm{SD}=0.86)$ female bears $\left(F_{1,33}=1.06, P=0.309\right)$. Nuisance males translocated $<5 \mathrm{~km}$ from their capture site $(n=11)$ were more likely $(72.7 \%)$ to repeat nuisance behaviors than nuisance males translocated $\geq 8 \mathrm{~km}(n=58$, $27.6 \%)$ from initial capture sites $\left(G_{1}=7.84, P=0.005\right)$. Pooled over a 6-year period, nuisance males were $15 \%$ more likely to survive fall archery and rifle season $(n=110$, $69.0 \%)$ compared to non-nuisance males $\left(n=72,54.0 \%, X_{2}^{2}=18.89, P<0.001\right)$.

Hunting mortality for the pooled 6-year rate was similar for nuisance $(n=23,30.4 \%)$ and non-nuisance $(n=73,30.1 \%)$ females $\left(X^{2}{ }_{2}=2.26, P=0.323\right)$.

We calculated the relationship of chest-girth circumference with weight $\left(r^{2}=0.92\right)$ among 335 black bears from southern West Virginia. Unlike previous studies, we report separate predictive equations regarding weight based on girth for both sex and behavior type; nuisance males [Weight $=-150.382+(2.546 \times$ girth $)]$, nuisance females [Weight $=$ $-49.446+(1.350 \times$ girth $)$ ], non-nuisance males [Weight $=-102.225+(2.020 \times$ girth $)$, and non-nuisance females [Weight $=-73.297+(1.644 \times$ girth $)]$. Nuisance bears weighed more and had a higher weight/girth ratio than non-nuisance bears. As age increased for male and female bears, weight, girth, and the weight/girth ratio increased as a quadratic function. 


\section{Acknowledgments}

Funding for this project was provided by the Northeast Wildlife Damage Management Cooperative, the West Virginia Division of Natural Resources, and the West Virginia University Division of Forestry.

Special thanks to my advisor Dr. James T. Anderson for giving me the opportunity to be part of a great project. I will always be grateful for your guidance throughout my academic career at West Virginia University. You helped me to overcome several obstacles when I needed help the most. I also thank Dr. John W. Edwards and Thomas L. Dotson for serving on my graduate committee. Also, special thanks to Christopher W. Ryan for always making time to answer my questions. Their insight and advice was invaluable throughout the course of this project.

Special thanks to the numerous West Virginia Division of Natural Resources personnel including G. Sharp, S. Houchins, E. Richmond, D. Arbogast, A. Worley, C. Lawson, R. Pettrey, J. Craft, E. Holland, R. Roles, L. Berry, J. Hajenga, C. Carpenter, and E. Thorn for trapping and handling bears. In particular, I thank J. Evans and P. Johansen for their support of this project.

I thank G. E. Seidel for his statistical assistance. I would have been lost in a maze of statistical output if it wasn't for your genius SAS abilities.

Special thanks go to Joe Osbourne, Daniel Sole, and John Simmons for helping me track these sometimes elusive animals. Your help was immeasurable for locating bears in the mountainous terrain of southern West Virginia.

A very deserved thank you to Trishia D. Costello who put up with me being absent over two whole summers while I chased not only bears, but also my dream. Thank you for your understanding while I pursued my masters degree. You have been an incredible asset, and I can never begin to thank you enough for what you have given me. 


\section{Table of Contents}

Abstract................................................................ ii

Acknowledgments................................................................ iii

Table of Contents........................................................... iv

List of Tables..................................................................... $\quad \mathbf{v}$

List of Figures................................................................ vi

Chapter 1: Nuisance black bear response to physical and auditory conditioning techniques in southern West Virginia

Abstract................................................................................ 1

Introduction............................................................................. 2

Study Area................................................................................. 4

Methods............................................................................. 5

Results............................................................................ 8

Movement (24-hour post release)........................................ 8

Nuisance Site Distance................................................... 9

Repeat Activities..................................................... 9

Discussion.......................................................................... 9

Release Response......................................................... 9

Proximity to Nuisance Sites.............................................. 10

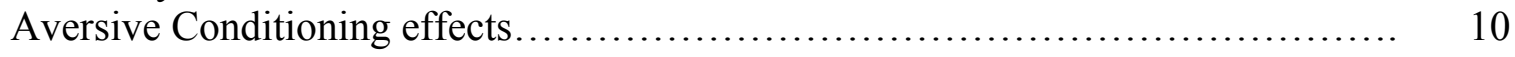

Summary and recommendations........................................... 10

Acknowledgments................................................................ 12

Literature Cited...................................................................... 12

Chapter 2: Physical and Behavioral Characteristics of Nuisance and Non-nuisance Black Bears in Southern West Virginia

Abstract........................................................................... 20

Introduction..................................................................... 21

Study Area............................................................................ 23

Methods.......................................................................... 24

Results....................................................................... 25

Initial Capture Age.......................................................... 25

Weight and Girth........................................................... 25

Translocation Effectiveness............................................. 26

Mortality Rates......................................................... 26

Litter Size............................................................. 26

Discussion.................................................................. 26

Hunter Harvest and Age Structure.......................................... 26

Translocations and Repeatability......................................... 27

Litter Size............................................................. 28

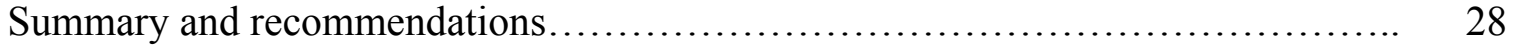

Acknowledgments.............................................................. 29

Literature Cited.............................................................. 29 
Chapter 3: Estimating nuisance and non-nuisance black bear weights using chestgirth circumference

Abstract............................................................................... 36

Introduction.................................................................. 37

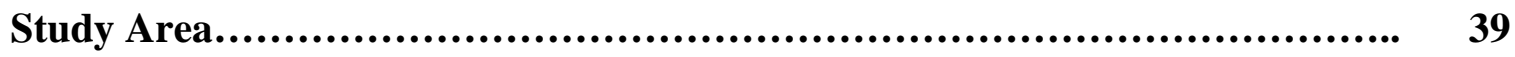

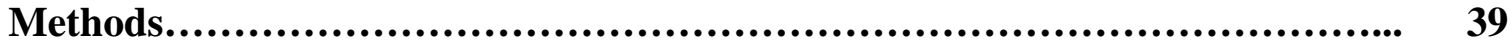

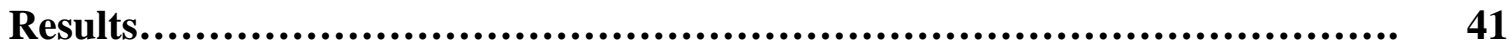

Girth and Weight Correlate................................................. 41

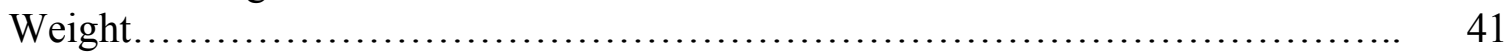

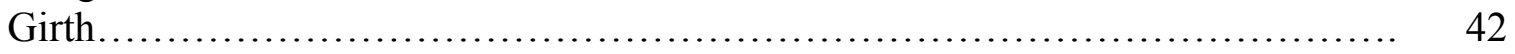

Weight to Girth Ratio....................................................... 42

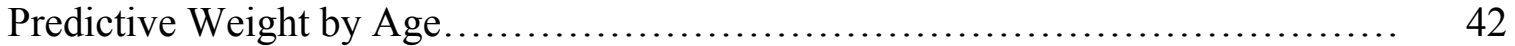

Predictive Girth by Age.................................................... 42

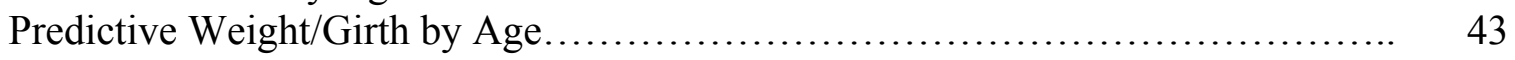

Discussion...................................................................... 43

Weight Prediction by Girth................................................. 43

Size Variables and Growth Trends............................................ 43

Management Implications.................................................... 45

Acknowledgments.............................................................. 46

Literature Cited............................................................. 46

\section{LIST OF TABLES}

\section{Chapter 1}

Table 1. Data collected from captured and released black bears from Kanawha, Boone, Logan, Mingo and Wyoming counties in southern West Virginia, 2003............ 18

\section{Chapter 2}

Table 1. Number of nuisance and non-nuisance bear captures by sex in southern West Virginia, 1996-2003.

Table 2. Nuisance black bear capture rate and repeat nuisance activity among both sexes by year, southern West Virginia, 1996-2002.

\section{Chapter 3}

Table 1. Black bear population estimates from Kanawha, Fayette, Raleigh, and Boone counties in southern West Virginia from1989-1998............................. 50

Table 2. Predictive equations estimating weight $(\mathrm{kg})$ from the measure of chest-girth circumference $(\mathrm{cm})$ for black bears in southern West Virginia. ...

Table 3. Age adjusted summary of weight, girth, and weight/girth measurements by gender and behavior type for black bears in southern West Virginia, 1996-2003. 
Table 4. Summary of weights $(\mathrm{kg})$ by age and gender for black bears in southern West Virginia, 1996-2003......................................................... 53

Table 5. Predictive equations estimating weight $(\mathrm{kg})$, girth $(\mathrm{cm})$, and the weight/girth $(\mathrm{kg} / \mathrm{cm})$ ratio based upon the age of black bears in southern West Virginia, 1996-2003.

\section{LIST OF FIGURES}

\section{Chapter 1}

Figure 1. Nuisance black bear study area in southern West Virginia, 2003.

Chapter 2

No Figures

\section{Chapter 3}

Figure 1. Predictive growth rates based on age cohorts for southern West Virginia black bears by gender and behavior type, 1996-2003

Figure 2. Predicted gains in weight and girth among age cohorts for black bears in southern West Virginia, 1996-2003. 
29 Nov 2004

James T. Anderson

Division of Forestry

West Virginia University

P.O. Box 6125

322 Percival Hall

Morgantown, WV 26506

304-293-2941 x 2445; FAX 304-293-2441; jander25@wvu.edu

RH: Nuisance bear conditioning response $\bullet$ Weaver et al.

Nuisance Black Bear Response To Physical and Auditory Conditioning Techniques in Southern West Virginia. ${ }^{A-}$

Harley W. Weaver, West Virginia University, Division of Forestry, P.O. Box 6125, Morgantown, WV 26506, USA, Evolven@aol.com

James T. Anderson, West Virginia University, Division of Forestry, P.O. Box 6125 Morgantown, WV 26506, USA

John W. Edwards, West Virginia University, Division of Forestry, P.O. Box 6125 Morgantown, WV 26506, USA

Thomas L. Dotson, West Virginia Division of Natural Resources, Route 1 Box 484, Point Pleasant, WV 25550-9734, USA

\begin{abstract}
Nuisance black bear (Ursus americanus) activity is increasing annually in southern West Virginia due to rising bear populations coupled with the availability of human refuse.

Efforts are currently underway to understand nuisance activity and possible management strategies to curb unwanted behavior. During 2003, 11 males and 1 female were captured and fitted with radio collars. Individuals were randomly assigned to receive either treatment $(n=6)$ or control $(n=6)$. Upon release, treatment individuals received a conditional regimen comprised of rubber buckshot to the flank and a succession of shell
\end{abstract}

A- This chapter is written in the style of Northeast Wildlife. 
crackers. During the first 2 hours following release, bears became sessile and remained stationary for 24 hours. After 4 days following post-treatment all bears appeared to resume normal movements. Based on direct observations all control and treatment bears resumed nuisance activity within 2 weeks of release. The physical and auditory conditioning techniques we used did not appear to be an effective means of reducing repeat nuisance behavior. Controlling food availability may be the best way to limit nuisance behavior. Understanding the limitations of physical and auditory conditioning techniques towards nuisance black bears may offer managers more efficient means to curb nuisance behavior.

Key words: aversive conditioning, black bear, nuisance, telemetry, Ursus americanus, West Virginia

Black bear populations have increased from historic lows and are currently expanding their range in Virginia (Virginia Department of Game and Inland Fisheries 2002), Pennsylvania (Ternent et al. 2001), and West Virginia. Black bear harvest levels increased at an annual rate of $6.3 \%$, between 1991-2000, from 500 to 900 animals in Virginia indicating a relative increase in population levels (Virginia Department of Game and Inland Fisheries 2002). Pennsylvania reports bear numbers have nearly tripled over the last 20 years (Ternent et al. 2001). In West Virginia, minimum population estimates indicated black bear numbers nearly quadrupled within a 10-year frame, 1989-1998, increasing at an average annual rate of $16.9 \%$ from 182 animals to 699 animals within a 4 county area (Kanawha, Fayette, Raleigh, and Boone) in southern West Virginia (J. Evans, WVDNR, personal communication).

As a result of land fragmentation and increasing human development, black bears are venturing into developed areas with increasing regularity (Saunders et al. 1991). 
Negative human-bear interactions will likely increase with growing bear populations in West Virginia and elsewhere. Those individuals interacting negatively with humans have been labeled problem, panhandler, or nuisance bears (Tate 1985, Mattson 1990).

Males generally represent a majority of nuisance activity (Rogers 1989, Mclean and Pelton 1990, Clark et al. 2002, Virginia Department of Game and Inland Fisheries 2002). During periods of low mast availability (Eagle and Pelton 1983, Rogers 1989, McLean and Pelton 1990, Igo 2001) nuisance behavior such as foraging on garbage (Rogers et al. 1976, Herrero 1983, McLean and Pelton 1990), agricultural crops (Davenport 1953, Landers et al. 1979, Elowe and Dodge 1989, Calvert et al. 1992, Maddrey and Pelton 1995), bee hives (Brady and Maehr 1982, Garner and Vaughan 1987, Wooding et al. 1988) and other items often increases. Monetary losses can reach into the millions of dollars in the U.S. (United States Department of Agriculture 2001, United States Department of Agriculture 2002). In 2002, West Virginia received 210 bear damage claims totaling $\$ 102,636$, including damage to personal property, livestock, and agricultural goods. Monetary losses in 2002 were $88.9 \%$ greater than in 2001 $(\$ 54,334)$ when only 138 bear damage claims were received (West Virginia Division of Natural Resources 2002).

Effective management strategies are necessary to facilitate the reduction or elimination of further nuisance activity. Current strategies for controlling nuisance activities include translocations (Sauer et. al. 1969, McArthur 1981, Massopust and Anderson 1984, Fies et. al. 1987, Shull 1994, Clark et. al. 2002), aversive conditioning by either repellants (Rogers 1984, McCarthy and Seavoy 1992, Herrero and Higgins 1995, Schirokauer and Boyd 1998) or deterrents (Brady and Maehr 1982, McCarthy and Seavoy 1992, Hygnstrom and Craven 1996, Ternent and Garshelis 1999), and euthanasia (T. L. Dotson, WVDNR). 
Currently, WVDNR personnel employ a 3-strikes policy for nuisance bear. During the first offense, nuisance bears are captured, drugged, marked with numbered orange ear tags, and tattooed on their inner lip. Depending on the individuals responding to the capture, offenders are either released near the disturbance site or transported to a wildlife management area. Typically, animals are released and receive a conditioning treatment with aerial shell crackers. Second offenses are often dealt with in the same manner. Third time offenders are destroyed. This treatment may be administered prior to the third offense for bears with highly aggressive behavior or those continuing nuisance activities that are unable to be trapped. However, the effectiveness of this treatment has not been evaluated.

Our objective was to evaluate the effectiveness of aversive conditioning techniques that may deter nuisance black bear behavior with minimal conditioning repetitions. Objectives of this study involve the evaluation of treatment (rubber buckshot and cracker shells) and control conditioning and its effect on bear movement and activities through radio telemetry tracking. Specific objectives included:

1. Determine movement patterns and activities during the 24 -hour post-release period;

2. Determine distance from dumpsters/nuisance sites in relation to bear positions generated through telemetry; and

3. Determine the effectiveness of conditioning techniques at eliminating repeat nuisance behavior.

\section{Study Area}

Our study was conducted in 5 counties (Kanawha, Boone, Logan, Mingo, and Wyoming) in southern West Virginia (Fig. 1). Elevation ranged from 173 to 1,063 m, and topography was generally steep. Major cover types included mixed-mesophytic 
hardwood forest, cove hardwood forest, and oak (Quercus spp.) dominated forest (United States Geological Survey 2002). Soils in this region are generally fine sandy loams to sandy loams (West Virginia University Natural Resources Center 2003). Mining of bituminous coal has heavily influenced this region. Deep mining, mountain top removal mining, and valley fill practices were the most common methods of coal extraction. Collectively, 317,279 residents lived in the 5 counties, which was $17.5 \%$ of the total West Virginia population in 2000 (West Virginia Health Statistics Center 2004). Kanawha County, the most urbanized region within the study, had the largest human population (200,073 residents) of the 55 counties in the state. Residential areas and mine sites are contributing to nuisance bear activity by providing ample supplies of accessible human refuse.

\section{Methods}

Prior to the nuisance bear activity period in 2003 , which generally runs from March to October, bears were randomly assigned to either control or treatment groups (dependent on order of capture) prior to the trapping season. Bears 2, 5, 6, 7, 10, and 12 were the control group while individuals $1,3,4,8,9$, and 11 were treated. Upon release, conditioned bears immediately received aversive physical and auditory stimuli. Control group bears were released without aversive conditioning treatments. We defined nuisance bears as individuals who demonstrated unwanted destructive behavior; including apiaries and bird feeders, but most often related to garbage consumption.

Once a nuisance complaint had been received, WVDNR personnel used trailermounted culvert traps baited with doughnuts to capture all bears. Generally, culvert traps were set within 24-48 hours following the complaint and captured animals were processed on-site. Each captured individual was tagged, recorded, measured, and processed in a similar manner (Weaver et al. 2003). The chemical immobilant Telazol ${ }^{\circledR}$ 
(1:1 mixture of tiletamine hydrochloride [HCL] and zolazepam HCL; Elkins-Sinn, Inc., Cherry Hill, NJ) was administered to individuals because it is safe and effective in contrast to other animal control agents (White et al. 1996). Telazol was administered at a rate of $5.0 \mathrm{mg} / \mathrm{kg}$ of body weight via a $\mathrm{CO}_{2}$ powered dart pistol. Biologists with the WVDNR removed 1 upper premolar from each individual to estimate age via cementum annuli counts (Willey 1974). Matson's Laboratory (Milltown, MT) sectioned and aged all teeth. Standard processing included numbered and colored (orange) ear tags, an upper lip tattoo coinciding with the numbered ear tags, and a fitted Advanced Telemetry Systems (ATS) M3200 (Advanced Telemetry Systems Inc., Isanti, MN) radio collar. Generally, 2-3 personnel were involved in processing the animal, and time from immobilization to release lasted approximately $4-5$ hours. Reference information regarding biological measures and associated treatment type was compiled for all bears (Table 1).

Individuals were released within $11 \mathrm{~km}$ of their capture site. Efforts were made to release animals near the site of capture, ensuring familiarity with their surroundings, while maintaining a 1-km buffer from any residence. This would presumably reduce stress on the animal and negate any aversive conditioning associated with release outside an individual's homerange. Upon release individuals received a conditioning treatment consisting of both 12-gauge rubber buckshot and explosive cracker shells. The rubber buckshot was administered to the animals flank (1-4 shots) at 10-40 meters to avoid penetrating the skin, but also avoiding shot spread and subsequent eye injury. Upon receiving the physical stimulus, 12-gauge cracker shells (1-8 shots) were shot toward the vicinity $(25-50 \mathrm{~m})$ of the animal to create an auditory stimulus.

Telemetry locations were recorded using an ATS R2000 unit and 2 element Hantenna. When conducting searches with a vehicle, a magnetized cab-mounted whip- 
type antenna was used to locate collared animals. The 2 element $\mathrm{H}$-antenna was then used to accurately locate the direction of the animal. Compass bearings were taken from 2-3 fixed telemetry stations. To reduce telemetry error, we attempted to visually locate animals and record their position except during the 24-hour post release. Readings more than $1 \mathrm{~km}$ from our position or 15 minutes apart were excluded from analysis to further reduce telemetry error. Aerial telemetry was used on 2 occasions for bears we were unable to find after intensive ground-based searches.

During 24-hour tracking periods, bears were tracked every 2 hours from the time of release. Within this period, we made no attempts to observe the bear's exact position to lessen the probability of alerting the bear to our presence and altering its post-release activities.

Telemetry positions were recorded using the loudest signal method (Springer 1979). Bearings were recorded with the minimum bearing being $\geq 40^{\circ}$ and the maximum bearing $\leq 130^{\circ}$. Each location for which we recorded a bearing was designated using the Universal Transverse Mercator (UTM) coordinate system. Each coordinate was assessed using a Brunton ${ }^{\circledR}$ Multi-Navigator TM Global Positioning System (Riverton, WY) receiver accurate to within $\pm 10 \mathrm{~m}$. All locations were recorded and transferred onto a 1:24,000 Quadrangle map overlaid with UTM grid cells. Radio telemetry tracking was conducted 5-7 days a week from 3 April 2003 through 15 August 2003.

Accuracy of ground telemetry was assessed by the 2 personnel that tracked the bears. Collars with transmitters were randomly placed from 50 to $1,000 \mathrm{~m}$ from a marked flag in fields, recently timbered tracts, and mature forested areas. We used linear distance to determine error from our estimated location to the actual radio collar location (Zimmerman and Powell 1995). Accuracy of distance errors were $\leq 100 \mathrm{~m}$ for both observers and similar to those described by Garshelis et al. (1982). 
The locations of radio-collared bears were determined by entering the UTM coordinates of the telemetry stations and the related bearings into the program LOCATE Version 2.82. Final UTM location points were transferred into ArcView GIS 3.2 for multi-layer map presentations. Data layers included bear locations, dumpster positions, and points of nuisance activity. Bear positions were analyzed relative to their distance $(\mathrm{km})$ from either dumpsters or nuisance activity sites with the ArcView Spatial Analysis extension tool. Distance traveled from point of release during the 24-hour survey was determined using the ArcView Measure tool.

A $\chi^{2}$ test was used to examine differences in distances from dumpsters or nuisance sites (often the point of capture) between treatment and control bears (PROC FREQ; SAS 2000). Comparing 24-hour travel distance and time of repeat nuisance activity between treatment and control bears was determined using a $t$-test (PROC TTEST; SAS 2000). A significance level of $\underline{\alpha}=0.05$ was used for all statistical tests.

\section{Results}

The WVDNR captured 12 nuisance bears (11 males, 1 female) from 2 April 2003 until 21 June 2003 within the 5-county study area. Although premolars were extracted, age results are not yet available. Bear SNB-003 shed his collar within hours after release and no data was obtained. SNB-011 was never located after the 24-hour survey, and likely moved to a remote area made unavailable to our vehicles. Post release data (24hour) for bears SNB-001 and SNB-005 were not recorded due to delay of capture information and travel constraints.

Upon release, nuisance bears moved a minimal distance during the entire 24-hour period. Tracked individuals $(n=9)$ became sessile within 2 hours after release and maintained their position for the extent of the 24-hour survey. There was no difference in distance traveled between treatment $(n=4, \bar{x}=751.4 \mathrm{~m}, \mathrm{SE}=443.7$, range $=150-2,040)$ 
and control $(n=5, \bar{x}=503.0 \mathrm{~m}, \mathrm{SE}=241.5$, range $=74-1,251)$ bears $\left(t_{8}=-0.52, P=\right.$ 0.61) during the first 24-hours.

Distance was calculated from a dumpster or nuisance site to the bear's estimated coordinates for both treatment $(n=72$ locations) and control $(n=83)$ bear locations using 3 distance measures; $<1 \mathrm{~km}, 1-2 \mathrm{~km}$, and $>2 \mathrm{~km}$. Treatment bear locations $(n=36$, $50.0 \%$, range $=2-26$ ) were $23.5 \%$ more likely to be found $<1 \mathrm{~km}$ from a known dumpster or nuisance site compared to control bear locations $(n=22,26.5 \%$, range $=$ $2-5) ; 12.6 \%$ more likely $(n=16,22.2 \%$, range $=2-7)$ to be found $1-2 \mathrm{~km}$ from a site than control bear locations $(n=8,9.6 \%$, range $=1-3)$, and $36.1 \%$ less likely $(n=20$, $27.8 \%$, range $=1-7)$ to be found $>2 \mathrm{~km}$ from a nuisance site than control bear locations $(n=53,63.9 \%$, range $\left.=1-15), \chi_{2}^{2}=20.29, P<0.001\right)$.

Following release, all bears $(n=10)$ repeated nuisance activities. There was no difference in days required to repeat nuisance behavior between treatment $(n=4, \bar{x}=8.3$ days, $\mathrm{SE}=2.9$, range $=1-13)$ and control $(n=6, \bar{x}=9.2$ days, $\mathrm{SE}=3.1$, range $=2-23)$ bears $\left(t_{9}=0.20, P=0.84\right)$

\section{Discussion}

During the 24-hour tracking period, bears became sessile shortly after release and remained immobile during that period. This occurred for both treatment and control groups. We had expected that animals receiving both physical and auditory stimuli would travel farther from the area where the conditioning response occurred. Treated bears traveled, on average, approximately $250 \mathrm{~m}$ farther than the control group before further movement ceased. However, this increased movement was not statistically different. Safe and effective use of the drug Telazol in black bears has been established in both field trials (White et al. 1996) and veterinary medicine (Caulkett and Cattet 2002). No prolonged or lasting effect has been established for this compound and appears to be a 
safe immobilant. We conclude that bears may have responded in a normal manner to stress-related exhaustion and the temporary anesthetic effect from the immobilant. This phenomenon may not be widely reported or simply overlooked since this sessile behavior appears temporary and no long-term effects have been described.

Bear positions were analyzed relative to their distance from either dumpsters or known nuisance activity sites. These areas were often the point of capture for each individual. However, mine operations often placed multiple dumpsters across the work site. We expected treatment-group bears to distance themselves from areas of nuisance activity resulting from the proximity of capture to these sites coupled with a conditioning regime. However, telemetry positions indicate treated animals were more likely found near dumpsters and former nuisance sites relative to the control group. This occurrence was relevant for distance measures from 0-2 km, while most control group observations occurred beyond the 2-km boundary. However, an increase in observational data for 1 individual (36\% of the 72 treatment observations) may skew these results. Also, increasing sample size may negate these findings.

There was no reduction in nuisance activity between the treatment and control groups. The associated stress of capture, chemical immobilization, or conditioning regime failed to eliminate further nuisance behavior. Similar findings were reported for nuisance bears in Alaska that received a combination of rubber buckshot and cracker shells (McCarthy and Seavoy 1994).

Nuisance black bear conditioning techniques vary not only in type and administration, but the reported response rate from such conditioning regimes. For instance, a substantial reduction in repeat nuisance activity was reported for trap and onsite release of apiary-raiding black bears not receiving a treatment regime (Brady and 
Maehr 1982, Wooding et al. 1988). Results of conditioning techniques appear to vary widely and may be highly dependent on the level of habituation to a food source.

Although the black bear population is expanding in southern West Virginia, the root cause of many nuisance activities is the readily available foods found on mine sites or near residential areas. The majority of refuse is easily accessible to bears and other wildlife. Bears subjected to aversive conditioning regimes may be overwhelmed by positive reinforcement from an easily attainable, high calorie food source. Any shortterm discomfort received under a narrow set of conditions is not likely to produce the desired aversion under conditions found at nuisance activity sites. Restricting the amount of available refuse is a key element in reducing nuisance activity (Herrero and Fleck 1990).

Education may provide large audiences with information relative to bear-human conflict reduction. Public education concerning detrimental causes and effects of nuisance activities may ensure successful implementation of procedures by the public to limit food availability. Such information can be disseminated through public meetings and news media. These avenues should be explored to educate the public with concerns to nuisance activity and prevention.

Translocating nuisance bears may be an effective means of reducing repeat behavior (McArthur 1981, Fies et al. 1987, Weaver et al. 2003). Other studies have reported nuisance activity after translocations either during homing or upon return to an individuals homerange (Alt et al. 1977, Massopust and Anderson 1984). Translocating nuisance animals may be an alternative to other management procedures, but fails to address the reason nuisance activity arises (McArthur 1981).

It appears unlikely that bears and people can be mutually excluded from one another. Therefore, efforts should be directed toward managing the interactions of both 
nuisance bears and people. By investing in forums targeting nuisance bear education and deterrent techniques aimed at refuse elimination, we can promote a positive existence with the black bear in southern West Virginia.

\section{Acknowledgments}

We thank the West Virginia Division of Natural Resources, the Northeast Wildlife Damage Management Cooperative, and the West Virginia University Davis College of Agriculture, Forestry, and Consumer Sciences (McIntire-Stennis) for funding this research. We thank the numerous West Virginia Division of Natural Resources personnel including G. Sharp, S. Houchins, E. Richmond, D. Arbogast, A. Worley, C. Lawson, R. Pettrey, J. Craft, E. Holland, R. Roles, L. Berry, J. Hajenga, C. Carpenter, and E. Thorn for trapping and handling bears. In particular, we thank J. Evans, P. Johansen, and C. Ryan for their support of this project. Statistical assistance provided by G. Seidel is also greatly appreciated. This is manuscript number 0000 of the West Virginia University Agricultural and Forestry Experiment Station.

\section{Literature Cited}

Alt, G. L., G. J. Matula, Jr., F.W. Alt, and J.S. Lindzey. 1977. Movements of translocated nuisance black bears of northeastern Pennsylvania. Transactions of the Northeast Fish and Wildlife Conference 34:119-126.

Brady, J. R. and D. S. Maehr. 1982. A new method of dealing with apiary-raiding black bears. Proceedings of the Annual Conference of Southeastern Association of Fish and Wildlife Agencies 36:571-577.

Calvert, R., D. Slate, and P. Debow. 1992. Approach to bear damage management in New Hampshire. Proceedings: Eastern Black Bear Workshop 11:96-107. 
Caulkett N., and M.R.L. Cattet. 2002. Anesthesia of bears. Zoological restraint and anesthesia. International Veterinary Information Service, Ithaca, New York, USA.

Clark, J. E., F. T. van Manen, and M.R. Pelton. 2002. Correlates of success for on-site releases of nuisance black bears in Great Smokey Mountains National Park. Wildlife Society Bulletin 30:104-111.

Davenport, L. B. 1953. Agricultural depredation by the black bear in Virginia. Journal of Wildlife Management 17:331-340.

Eagle, T. C. and M. R. Pelton. 1983. Seasonal nutrition of black bears in the Great Smokey Mountains National Park. International Conference of Bear Research and Management 5:94-101.

Elowe, K. D. and W. E. Dodge. 1989. Factors affecting black bear reproductive success and cub survival. Journal of Wildlife Management 53:962-968.

Fies, M. L., D. D. Martin, and G. T. Blank, Jr. 1987. Movements and rates of return of translocated black bears in Virginia. International Conference on Bear Research and Management 7:369-372.

Garner, N. P., and M. R. Vaughn. 1987. Black bears' use of abandoned homesites in Shenandoah National Park. International Conference on Bear Research and Management 7: 151-157.

Garshelis, D. L., H. B. Quigley, C. R. Villarrubia, and M. R. Pelton. 1982. Assessment of telemetric motion sensors for studies of activity. Canadian Journal of Zoology 60:1800-1805.

Herrero, S. 1983. Social behavior of black bears at a garbage dump in Jasper National Park. International Conference of Bear Resource Management 5:54-70. 
, and S. Fleck. 1990. Injury to people inflicted by black, grizzly, and polar bears:

recent trends and new insights. International Conference of Bear Resource Management 8:25-32.

, and A. Higgins. 1995. Fatal injuries inflicted to people by black bear. Proceedings of the Western Black Bear Workshop 5:75-81.

Hygnstrom, S. and S. Craven. 1996. Bear damage and abatement in Wisconsin. Board of Regents of the University of Wisconsin System.

Igo, W. K. 2001. West Virginia Status Report. Eastern Workshop on Black Bear Resources and Management 16:88-98.

Landers, J. L., R. J. Hamilton, A. S. Johnson, and R. L. Marchinton. 1979. Foods and habitat of black bears in southeastern North Carolina. Journal of Wildlife Management 43:143-153.

Maddrey, R. C. and M. R. Pelton. 1995. Black bear damage to agricultural crops in coastal North Carolina. Proceedings of the Annual Conference of Southeastern Association of Fish and Wildlife Agencies 49:570-579.

Massopust, J. L. and R. K. Anderson. 1984. Homing tendencies of translocated nuisance black bears in northern Wisconsin. Proceedings of the Eastern Workshop on Black Bear Research and Management 7:66-73.

Mattson, D. J. 1990. Human impacts on bear habitat use. International Conference of Bear Research and Management 8:33-56.

McArthur, K. L. 1981. Factors contributing to effectiveness of black bear transplants. Journal of Wildlife Management 45: 102-110.

McCarthy, T. M. and R. J. Seavoy. 1994. Reducing non-sport losses attributable to food conditioning: Human and bear behavior modification in an urban environment. International Conference on Bear Research and Management 9:75-84. 
McLean, P. K. and M. R. Pelton. 1990. Some demographic comparisons of wild and panhandler bears in the Smokey Mountains. International Conference of Bear Research and Management 8:105-112.

Rogers, L. L. 1984. Reactions of free-ranging black bears to capsaicin spray repellent. Wildlife Society Bulletin 12:59-61. . 1989. Black bears, people and garbage dumps in Minnesota. Pages 43-46 in M. Bromley, ed., Bear-people conflicts: proceedings of a symposium on management strategies. Northwest Territories Dept. of Natural Resources, Yellowknife, NWT. , D. W. Kuehn, A. W. Erickson, E. M. Harger, L. J. Verme, and J. J Ozoga. 1976. Characteristics and management of black bears that feed in garbage dumps, campgrounds or residential areas. International Conference of Bear Research and Management 3: 169-175.

Sauer, P. R., S. Free, and S. Browne, 1969. Movement of tagged black bears in the Adirondacks. New York Fish and Game Journal 16:205-223.

Saunders, D. A., R. J. Hobbs, and C. R. Margules. 1991. Biological consequences of ecosystem fragmentation: a review. Conservation Biology 5:18-32.

SAS. 2000. SAS user's guide: statistics, version 8 edition. SAS Institute, Inc. Cary, North Carolina, USA.

Schirokauer, D. W., and H. M. Boyd. 1998. Bear-human conflict management in Denali National Parkand Preserve 1982-94. Ursus 10:395-403.

Shull, S. D. 1994. Management of nuisance black bears (Ursus americanus) in the interior highlands of Arkansas. Master's Thesis. University of Arkansas, Fayetteville, Arkansas, USA.

Springer, J.T. 1979. Some sources of bias and sampling error in radio triangulation. Journal of Wildlife Management 43:926-935. 
Tate, J. 1985. A profile of panhandling black bears in the Great Smokey Mountains National Park. Doctoral dissertation. University of Tennessee, Knoxville, Tennessee, USA.

Ternent, M. A., T. Conway, R. M. Hough, G. Feaser, R. D. Buss, S. E. Harshaw, and M. S. Rutkowski. 2001. Recommendations for reducing nuisance black bear conflicts in Pennsylvania. Nuisance Black Bear Management Committee, Pennsylvania Game Commission, Harrisburg, PA, USA. 24 p.

Ternent, M. A., and D. L. Garshelis. 1999. Taste-aversion conditioning to reduce nuisance activity by black bears in a Minnesota military reservation. Wildlife Society Bulletin 27:720-728.

U.S. Department of Agriculture (USDA). 2000. Sheep and goats predator loss. National Agricultural Statistics Service. http://jan.mannlib.cornell.edu/reports/nassr/livestock/pct-bbpl/ctpr0501.txt .2001. U.S. cattle and calves predator loss. National Agricultural Statistics Service. http://jan.mannlib.cornell.edu/reports/nassr/livestock/pgg-bbsg/predan00.txt

U.S. Geological Survey (USGS). 2002. A gap analysis of West Virginia: final report and data. Natural Resources Analysis Center, West Virginia University, Morgantown, West Virginia, USA.

Virginia Department of Game and Inland Fisheries. 2002. Virginia Black Bear Management Plan (2001-2010). Virginia Department of Game and Inland Fisheries, Verona, VA, USA. 103 p.

Weaver, H. W., J. T. Anderson, J. W. Edwards, and T. L. Dotson. 2003. Physical and behavioral characteristics of nuisance and non-nuisance black bears in southern West Virginia. Proceedings of the Southeastern Association of Fish and Wildlife Agencies 57:308-316. 
West Virginia Division of Natural Resources. 2002. West Virginia Big Game Bulletin 03-02, Charleston, West Virginia, USA.

West Virginia Health Statistics Center. 2004. A look at West Virginia's population by decade, 1950-2000, Brief No. 8. http://www.wvdhhr.org/bph/oehp/hsc/briefs/eight/table5.htm

West Virginia University Natural Resources Analysis Center. 2003. College of Agriculture, Forestry, and Consumer Sciences. West Virginia University, Morgantown, West Virginia, USA.

White, T. H. Jr., M. K. Oli, B. D. Leopold, H. A. Jacobson, and J. W. Kasbolm. 1996. Field evaluation of Telazol ${ }^{\circledR}$ and ketamine-xylazine for immobilizing black bears. Wildlife Society Bulletin 24:521-527.

Willey, C. H. 1974. Aging black bears from first premolar tooth sections. Journal of Wildlife Management 38:97-100.

Wooding, J. B., N. L. Hunter, and T. S. Hardisky. 1988. Trap and release apiary-raiding bears. Proceedings of the Annual Conference of Southeastern Association of Fish and Wildlife Agencies 42:333-336.

Zimmerman, J. W. and R. A. Powell. 1995. Radio telemetry error: location error method compared to error polygons and error ellipses. 1995. Canadian Journal of Zoology 73: 1123-1133. 
Table 1. Data collected from captured and released black bears from Kanawha, Boone, Logan, Mingo and Wyoming Counties in southern West Virginia, 2003.

\begin{tabular}{cccccl}
\hline $\begin{array}{c}\text { Identification } \\
\text { Number }\end{array}$ & Sex & Capture date & Mass $(\mathrm{kg})$ & Girth $(\mathrm{cm})$ & Conditioning type \\
\hline SNB-001 & M & $04 / 02 / 03$ & 172.7 & 124.5 & Treatment \\
SNB-002 & M & $04 / 07 / 03$ & 138.6 & 109.2 & Control \\
SNB-003 & M & $04 / 09 / 03$ & 115.9 & 106.7 & Treatment \\
SNB-004 & M & $04 / 19 / 03$ & 145.5 & 116.8 & Treatment \\
SNB-005 & M & $04 / 30 / 03$ & 150.0 & 114.3 & Control \\
SNB-006 & M & $05 / 07 / 03$ & 261.4 & 149.9 & Control \\
SNB-007 & M & $05 / 10 / 03$ & 170.5 & 118.1 & Control \\
SNB-008 & M & $05 / 29 / 03$ & 123.2 & 109.2 & Treatment \\
SNB-009 & M & $05 / 29 / 03$ & 155.5 & 132.1 & Treatment \\
SNB-010 & M & $05 / 31 / 03$ & 157.3 & 114.3 & Control \\
SNB-011 & M & $06 / 08 / 03$ & 147.7 & 123.2 & Treatment \\
SNB-012 & F & $06 / 21 / 03$ & 77.3 & 88.9 & Control \\
\hline & & & & & \\
\hline
\end{tabular}


Figure 1. Nuisance black bear study area in southern West Virginia, 2003.
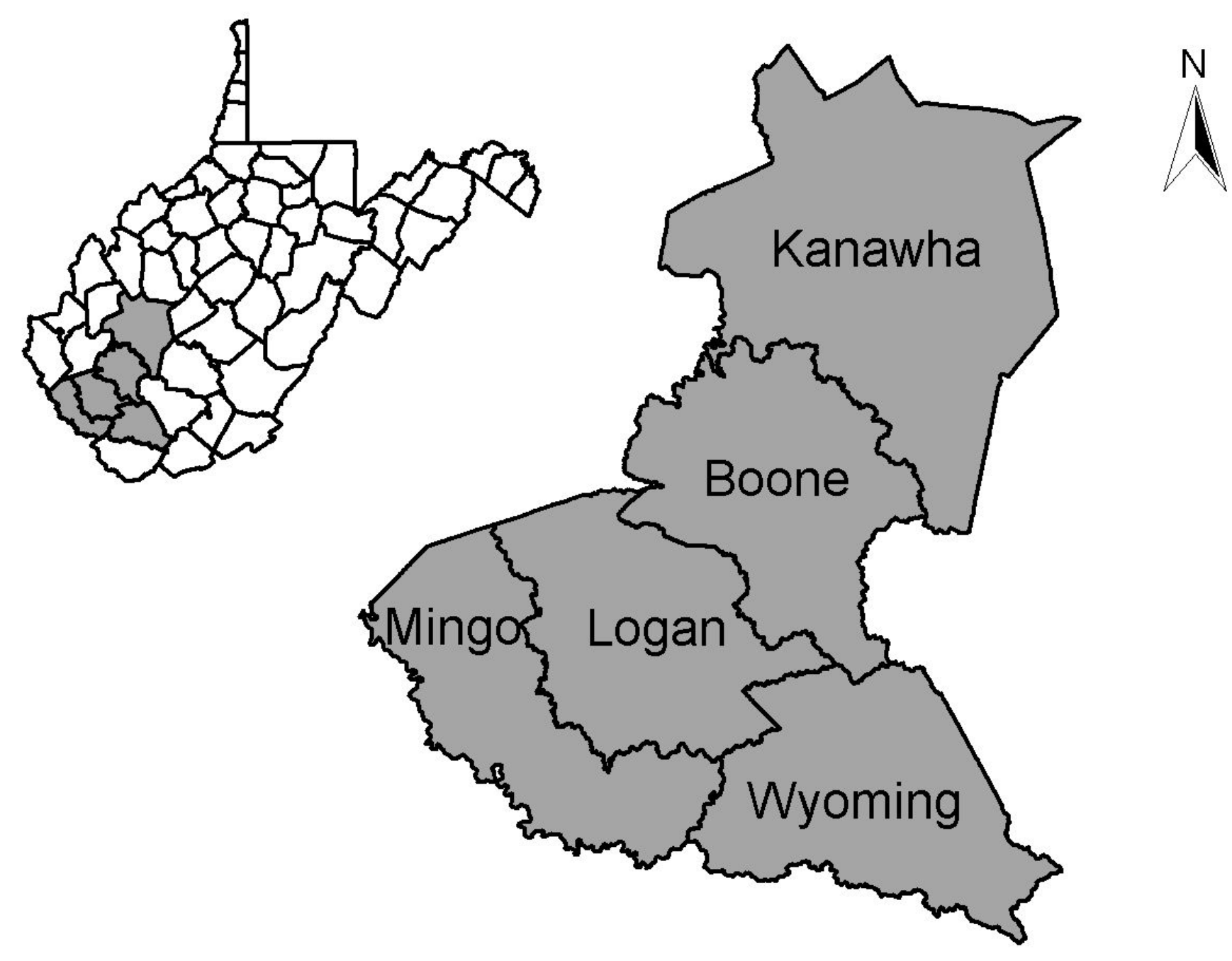
29 Nov 2004

James T. Anderson

West Virginia University

Division of Forestry

P.O. Box 6125

322 Percival Hall

Morgantown, WV 26506

304-293-2941 x 2445

jander25@wvu.edu

RH: Nuisance Black Bears • Weaver et al.

Physical and Behavioral Characteristics of Nuisance and Non-nuisance Black Bears in Southern West Virginia ${ }^{\mathrm{A}-}$

Harley Wayne Weaver, West Virginia University, Division of Forestry, P.O. Box 6125

Morgantown, WV 26506

James T. Anderson, West Virginia University, Division of Forestry, P.O. Box 6125

Morgantown, WV 26506

John W. Edwards, West Virginia University, Division of Forestry, P.O. Box 6125

Morgantown, WV 26506

Thomas L. Dotson, West Virginia Division of Natural Resources, Route 1 Box 484, Point

Pleasant, WV 25550-9734

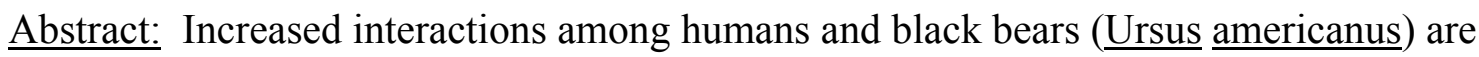
spurring increased concerns over property damage and human safety. These concerns become more apparent with habitat loss and fragmentation, particularly in relation to urban situations. To better understand the behavior and ecology of nuisance and nonnuisance black bears, the West Virginia Division of Natural Resources (WVDNR) captured 179 (151 males, 28 females) nuisance and 156 (77 males, 79 females) nonnuisance individuals from 1996 to 2003 . Sample sizes for each analysis were lower due to missing or incomplete data. Initial age of capture was greater for nuisance $(\underline{\mathrm{N}}=133$,

A- This chapter was written in the style of the Proceedings of the Annual Conference of the Southeast Fish and Wildlife Agencies. 
$\overline{\mathrm{x}}=3.77 \mathrm{yr}, \mathrm{SE}=0.21)$ than non-nuisance $(\underline{\mathrm{N}}=105, \underline{\bar{x}}=3.39 \mathrm{yr}, \mathrm{SE}=0.26)$ bears $(\underline{\mathrm{F}} 1$, $\left.{ }_{234}=19.28, \underline{\mathrm{P}}<0.001\right)$. Mean litter size was similar for nuisance $(\underline{\mathrm{N}}=19, \underline{\bar{x}}=3.16 \mathrm{cubs}$, $\mathrm{SD}=0.93)$ and non-nuisance $(\underline{\mathrm{N}}=37, \underline{\bar{x}}=2.65 \mathrm{cubs}, \mathrm{SD}=0.86)$ female bears $\left(\underline{\mathrm{F}}_{1,33}=\right.$ $1.06, \underline{\mathrm{P}}=0.309)$. Nuisance males translocated $<5 \mathrm{~km}$ from their capture site $(\underline{\mathrm{N}}=11)$ were more likely $(72.7 \%)$ to repeat nuisance behaviors than nuisance males translocated $\geq 8 \mathrm{~km}(\underline{\mathrm{N}}=58,27.6 \%)$ from initial capture sites $\left(\underline{\mathrm{G}}_{1}=7.84, \underline{\mathrm{P}}=0.005\right)$. Pooled over a 6-year period, nuisance males were $15 \%$ more likely to survive fall archery and rifle season $(\underline{\mathrm{N}}=110,69.0 \%)$ compared to non-nuisance males $\left(\underline{\mathrm{N}}=72,54.0 \%, \underline{X}^{2}{ }_{2}=18.89\right.$, $\underline{\mathrm{P}}<0.001)$. Hunting mortality was similar for nuisance $(\underline{\mathrm{N}}=23,30.4 \%)$ and nonnuisance $(\underline{\mathrm{N}}=73,30.1 \%)$ females $\left(\underline{\mathrm{X}}_{2}{ }_{2}=2.26, \underline{\mathrm{P}}=0.323\right)$. Removing nuisance bears from their point of capture appears to be relatively effective in reducing future nuisance problems. Innovative means of increasing hunting mortality of nuisance bears, while maintaining mortality rates of non-nuisance bears should be addressed in future studies. $\underline{\text { Key words: }}$ black bears, damage, $\underline{\text { Ursus americanus, }}$ West Virginia.

Proc. Annu. Conf. Southeast Assoc. Fish and Wildl. Agencies 57: 308-316

Interactions among black bears (나sus americanus) and humans are manifesting themselves with increasing regularity. Land fragmentation and the associated loss of habitat is a clear and prominent contributing factor fueling such interactions (Saunders et al. 1991). Habitat loss and human disturbance through mountain top removal mining and valley fill, agricultural, residential, urban, and recreational development promotes instances of negative exchanges between bears and humans (Hellgren and Maehr 1992, Balcerzak and Wood 2003). These incidents are resulting in damage to agricultural and 
personal properties, and pose a risk to human health and safety (Singer and Bratton 1980, Herrero and Fleck 1990, Calvert et al. 1992).

Generally, nuisance black bear activity can be attributed to seasonal variations in mast production where nutritional forage is limiting, especially in early spring or in poor mast years (Eagle and Pelton 1983, McLean and Pelton 1989). However, bears are an opportunistic species that concentrate foraging efforts on high quality human-related foods throughout the year (Herrero 1983, McLean and Pelton 1989). Edible human refuse and agricultural crops are substantial items in the diets of some black bears (Mattson 1990).

As human developments continue to expand into forested regions regularly used by bears, the potential for conflicts increase (Martinka 1982, Herrero and Fleck 1990). National and state parks and forests harbor a significant number of black bears, of which some frequently come into direct contact with tourists (McLean and Pelton 1989). Residential conflicts result in damage to homes, storage facilities and associated personal property (Calvert et al. 1992, Shull 1994, Virginia Department of Game and Inland Fisheries 2001). Many of these situations stem from food-conditioned animals feeding on human refuse or receiving handouts from local inhabitants (Calvert et al. 1992, Shull 1994). These interactions create habituated animals or "panhandler bears" that look to visitors for regular handouts (Tate 1985) and can result in human injury or death (Herrero and Higgins 1994). Often, garbage is the initial element that draws black bears to residential areas (Herrero 1983, Calvert et al. 1992). In southern West Virginia, nuisance bears are often drawn to open dumpsters on active mine sites as well as residential refuse.

Agricultural damage from black bears include losses to field crops, apiaries, fruit trees, orchards, and livestock (Davenport 1953, Landers et al. 1979, Brady and Maehr 
1982, Wooding et al. 1988, Elowe and Dodge 1989, Maddrey and Pelton 1995).

Nationwide, bears were responsible for the loss of 2,800 head of cattle in 2000, with damages estimated to be US\$1.8 million (United States Department of Agriculture 2001) while sheep losses totaled \$555,000 in 1999 (United States Department of Agriculture 2000). In 2002, black bear depredation costs totaled $\$ 102,636$ throughout West Virginia, including damage to personal property, livestock, and agricultural goods (West Virginia Division of Natural Resources 2002).

A better understanding of nuisance black bear ecology and behavior is necessary to manage and reduce potential conflicts. Black bear management strategies may become more effective in relation to human encroachment and disturbances if characteristics of nuisance and non-nuisance black bears are evaluated. Therefore, our study objectives were to evaluate differences in litter size, age, girth, weight, cub sex ratios, and mortality between behavior types (nuisance and non-nuisance) and, where applicable, gender. Furthermore, we evaluated the effect of onsite release versus translocation for nuisance male bears. We defined nuisance bears as individuals who demonstrated unwanted destructive behavior resulting in property damage.

\section{STUDY AREA}

Our study was conducted in seven southern West Virginia counties (Boone, Fayette, Kanawha, Logan, Mingo, Raleigh, and Wyoming) located between Charleston and Beckley, West Virginia. Topography was steep, with elevation ranging from 173 to $1063 \mathrm{~m}$. Major cover types on the study area included mixed-mesophytic hardwood forest, cove hardwood forest, and oak (Quercus spp.) dominated forest (United States Geological Survey 2002). According to the 2000 census, 418,582 residents lived in the seven counties, which was $23.1 \%$ of the total West Virginia population (West Virginia 
Health Statistics Center 2003). Kanawha County had the largest human population of the 55 counties in the state.

\section{METHODS}

West Virginia Division of Natural Resources (WVDNR) personnel captured nuisance black bears using baited culvert traps near residential or commercial buildings after a nuisance complaint had been filed, and captured non-nuisance black bears using modified Aldrich type foot snares (Johnson and Pelton 1980) in forested habitats. Personnel with the WVDNR immobilized captured individuals with Telazol (1:1 mixture of tiletamine hydrochloride and zolazepam hydrochloride; Elkins-Sinn, Inc., Cherry Hill, N.J.) and recorded: sex, weight, girth, and characteristic markings (scars, physical abnormalities). We classified black bears by sex, age, and behavior type (nuisance or non-nuisance).

Each black bear received a numbered and color-coded ear tag (orange for nuisance; black for non-nuisance), an upper lip tattoo corresponding to the ear tag number, and 100 individuals received a VHF radio transmitter. Biologists with the WVDNR removed one premolar tooth from each individual to estimate age via cementum annuli counts (Willey 1974). Non-nuisance bears and nuisance females were released on-site. Nuisance males were released on-site $(<5 \mathrm{~km})$ or translocated $\geq 8 \mathrm{~km}$ to a wildlife management area. We measured translocation distance using the straight-line distance from point of capture to releases site.

Annual den visits of females equipped with radio transmitters were conducted from mid-February through March. Females were immobilized while in the den and once removed, weight, girth, physical condition, litter size, cub sex, and nape hair length among cubs (to approximate birth date), were recorded (Bridges et al. 2002). 
We used two-way analysis of variance (ANOVA; PROC GLM; SAS 2000) to compare initial age of capture, weight, and girth between sex and behavior (nuisance or non-nuisance) groups. We compared litter size and proportion of male cubs in the litter among female behavior types and ages using two-way ANOVA. We used a $\underline{\mathrm{G}}$-test of independence to evaluate repeat nuisance behavior between translocated (moved $\geq 8 \mathrm{~km}$ ) and non-translocated $(<5 \mathrm{~km})$ black bears. $\mathrm{A} \underline{X}^{2}$ test was used to examine differences in mortality rates from hunter harvest between nuisance and non-nuisance black bears from mandatory check stations (PROC FREQ; SAS 2000). Mortality rates were pooled across the 6-year period and thus represent a cumulative mortality. A significance level of $\underline{\alpha}=$ 0.05 was used for all statistical tests.

\section{RESULTS}

The WVDNR captured 335 bears from 1996-2003 (Table 1). However, sample sizes for each analysis were lower due to missing or incomplete data. Sample size was lower in hunter harvest among nuisance $(\underline{\mathrm{N}}=151$ males, $\underline{\mathrm{N}}=28$ females $)$ and nonnuisance $(\underline{\mathrm{N}}=77$ males, $\underline{\mathrm{N}}=79$ females $)$ bears due to vehicle related deaths or from bears being destroyed due to repeat nuisance behavior.

Initial age (years) of capture was greater for nuisance $(\underline{\mathrm{N}}=133, \overline{\mathrm{x}}=3.77, \mathrm{SE}=$

$0.21)$ than non-nuisance $(\underline{\mathrm{N}}=105, \overline{\mathrm{x}}=3.39, \mathrm{SE}=0.26)$ bears $\left(\underline{\mathrm{F}}_{1,234}=6.62, \underline{\mathrm{P}}=0.011\right)$. Initial age of capture also was greater for female $(\underline{N}=75, \bar{x}=4.59, \mathrm{SE}=0.35)$ than male $(\underline{\mathrm{N}}=163, \overline{\mathrm{x}}=3.15, \mathrm{SE}=0.16)$ bears $\left(\underline{\mathrm{F}}_{1,234}=19.28, \underline{\mathrm{P}}<0.001\right)$. Males involved in nuisance activity upon initial capture and following release were older at initial capture $(\underline{\mathrm{N}}=24, \underline{\bar{x}}=4.13, \mathrm{SD}=2.77$, Range $1-12)$ than males $(\underline{\mathrm{N}}=45, \overline{\mathrm{x}}=3.38, \mathrm{SD}=2.16$, Range 1-8) not demonstrating repeat nuisance activity $\left(\underline{\mathrm{F}}_{1,65}=4.36, \underline{\mathrm{P}}=0.041\right)$.

Weight was greater for male $(\underline{\mathrm{N}}=147, \underline{\bar{x}}=95.8 \mathrm{~kg}, \mathrm{SD}=40.2)$ than for female $(\underline{\mathrm{N}}=66, \overline{\underline{x}}=63.8 \mathrm{~kg}, \mathrm{SD}=17.1)$ bears $\left(\underline{\mathrm{F}}_{1,176}=85.28, \underline{\mathrm{P}}<0.001\right)$. Girth was greater 
for male $(\underline{N}=87, \underline{\bar{x}}=96.6 \mathrm{~cm}, \mathrm{SD}=16.5)$ than for female $(\underline{N}=51, \underline{\bar{x}}=83.6 \mathrm{~cm}, \mathrm{SD}=$ 8.7) bears $\left(\underline{\mathrm{F}}_{1,176}=26.99, \underline{\mathrm{P}}<0.001\right)$.

Nuisance males translocated $<5 \mathrm{~km}$ from their capture site $(\underline{\mathrm{N}}=11)$ were more likely $(72.7 \%)$ to repeat nuisance behaviors than nuisance males translocated $\geq 8 \mathrm{~km}(\underline{\mathrm{N}}=$ $58,27.6 \%)$ from initial capture sites $\left(\underline{\mathrm{G}}_{1}=7.84, \underline{\mathrm{P}}=0.005\right)$. Nuisance males were translocated $8 \mathrm{~km}$ to $68 \mathrm{~km}(\underline{\mathrm{N}}=58, \underline{\bar{x}}=40.1, \mathrm{SD}=11.6)$. Only one nuisance female was translocated $>8 \mathrm{~km}$, and therefore females were not analyzed. Repeat nuisance activity was often, but not always documented during the same year as initial capture (Table 2). Nuisance males $(\underline{\mathrm{N}}=110)$ were $15 \%$ more likely to survive fall archery and rifle season $(69.0 \%)$ compared to non-nuisance males $\left(\underline{\mathrm{N}}=72,54.0 \%, \underline{X}_{2}^{2}=18.89, \underline{\mathrm{P}}<\right.$ 0.001). Archery season accounted for $47.1 \%$ of the known mortality in nuisance males and $36.4 \%$ of the mortality in non-nuisance males. Hunting mortality was similar for nuisance $(\underline{\mathrm{N}}=23,30.4 \%)$ and non-nuisance $(\underline{\mathrm{N}}=73,30.1 \%)$ females $\left(\underline{\mathrm{X}}_{2}{ }_{2}=2.26, \underline{\mathrm{P}}=\right.$ $0.323)$.

Mean litter size was similar for nuisance $(\underline{\mathrm{N}}=19, \underline{\bar{x}}=3.16, \mathrm{SD}=0.93)$ and nonnuisance $(\underline{\mathrm{N}}=37, \underline{\bar{x}}=2.65, \mathrm{SD}=0.86)$ female bears $\left(\underline{\mathrm{F}}_{1,33}=1.06, \underline{\mathrm{P}}=0.309\right)$. There was no interaction for proportion of male cubs in the litter among age and behavior types $\left(\underline{\mathrm{F}}_{1,38}=0.58, \underline{\mathrm{P}}=0.45\right)$. The proportion of male bear cubs for nuisance females $(\underline{\mathrm{N}}=19$, $\bar{x}=0.49, \mathrm{SD}=0.27)$ and non-nuisance females $(\underline{\mathrm{N}}=37, \overline{\mathrm{x}}=0.44, \mathrm{SD}=0.32)$ was similar.

\section{DISCUSSION}

Captured nuisance bears were older than bears not demonstrating nuisance activity. Among both behavior types, female mean age was greater than males. Nuisance male bears also were less likely to be harvested during the fall archery and rifle seasons. These two parameters are probably related. It appears at least for males that 
older age structures occur in urban populations compared to rural populations. The preponderance of males in most harvest samples can be a reflection of a larger home range making the individual more susceptible to hunting; while higher harvest rates can signify reduced age structure if harvest regulations remain constant (Bunnel and Tait 1977). An older age structure would be supported by smaller homeranges observed in females (Alt et al. 1977, Garshelis and Pelton 1981, Pacas and Paquet 1994). Nuisance bears of both sexes may have smaller home ranges in response to meeting their nutritional requirements from refuse. Beckmann and Berger (2003) reported a significant decrease in black bear homerange, both male (90\%) and female (70\%), at the urbanwildland interface than wildland areas. Therefore, non-nuisance males inhabiting wildland areas would likely have a lower mean age compared to nuisance males due to increased harvest rates. The findings of Beckmann and Berger (2003) lend support to our analysis and conclusions among male behavior types.

Removing nuisance bears from sites where they caused damage appears to be an effective means of reducing short-term repeat nuisance behavior. Wildlife managers may find releasing younger individuals onsite or translocating them a lesser distance may be advantageous compared to older individuals who are more likely to repeat nuisance behavior. Relocated bears may not be as dependent on garbage or other food source that initially attracted them (Tate 1985, Mattson 1990). Alternatively, it may be due to where bears were relocated. Putting a nuisance bear into another developed area likely will not reduce repeat nuisance behavior as a variety of factors affect bear response (Clark et al. 2002). For example, bears do not necessarily avoid areas with roads and are probably driven more by natural than artificial food supplies (Carr and Pelton 1984). Moving bears away from urban areas and into remote areas should decrease the likelihood of repeat nuisance behavior. However, a decrease in documented repeat nuisance activity 
may arise by a roaming individual reestablishing a homerange, and not persisting in one localized area to create a noticeable problem. Massopust and Anderson (1984) reported that $43 \%$ of nuisance males translocated an average of $62.4 \mathrm{~km}$ repeated nuisance behavior. In our study, nuisance males were translocated a mean distance of $40.1 \mathrm{~km}$, but only $27.6 \%$ were reported repeating nuisance behavior. Repeat nuisance male behavior from on site release was significantly greater than for apiary-raiding males $(19.5 \%)$ indicated by Wooding et al. (1988). However, these data should be interpreted with some caution, because relocated bears may not be as likely to be reported as bears that continue to cause nuisance problems near the original site of capture.

The mean litter size of 3.16 in nuisance bears was similar to bears in northeastern Pennsylvania, where the largest average litter size in the United States was thought to exist (Alt 1989). Alt (1989) believed their large litter size was due to favorable growing conditions in the region. The large litter size of our bears may be due to equally high availability of food resources in southern West Virginia. Alt (1989) concluded that cub sex ratios do not differ significantly from 50:50 in Pennsylvania. Our results were comparable, and overall cub sex ratios did not vary significantly from 50:50.

In light of increasing black bear-human interactions, increased knowledge of black bear ecology and behavior is necessary to manage potential conflicts. These data contribute to our understanding of both nuisance and non-nuisance bear ecology in the Central Appalachians. It is clear that traditional hunting methods are not as effective in harvesting nuisance males compared to non-nuisance males. Wildlife managers may consider a special urban archery hunt when dealing with nuisance black bears that frequent developed areas. However, the modification of human behavior may have the greatest impact. Black bear nuisance behavior in urban areas will likely persist unless access to human refuse is effectively eliminated. Further research addressing home- 
range size and response to aversive conditioning techniques is required to fully understand how to manage nuisance black bears.

\section{ACKNOWLEDGMENTS}

We thank the West Virginia Division of Natural Resources, the Northeast Wildlife Damage Management Cooperative, and the West Virginia University Davis College of Agriculture, Forestry, and Consumer Sciences (McIntire-Stennis) for funding this research. We thank the numerous West Virginia Division of Natural Resources personnel including G. Sharp, S. Houchins, E. Richmond, D. Arbogast, A. Worley, C. Lawson, R. Pettrey, J. Craft, E. Holland, R. Roles, L. Berry, J. Hajenga, C. Carpenter, and E. Thorn for trapping and handling bears. In particular, we thank J. Evans, P. Johansen, and C. Ryan for their support of this project. We thank J. Evans, C. Ryan, M. Vaughan and two anonymous referees for evaluating the manuscript. Statistical assistance provided by G. Seidel also is greatly appreciated. This is manuscript number 2851 of the West Virginia University Agricultural and Forestry Experiment Station.

\section{LITERATURE CITED}

Alt, G.L. 1989. Reproductive biology of female black bears and early growth and development of cubs in northeastern Pennsylvania. Doctoral dissertation. West Virginia University, Morgantown.

, G.J. Matula, Jr., F.W. Alt, and J.S. Lindzey. 1977. Movements of translocated nuisance black bears of northeastern Pennsylvania. Transactions of the Northeast Fish and Wildlife Conference 34:119-126.

Balcerzak, M.J. and P.B. Wood. 2003. Red-shouldered hawk (ㅂuteo lineatus) abundance and habitat in a reclaimed mine landscape. Journal of Raptor Research 37:188197. 
Beckmann, J.P. and J. Berger. 2003. Using black bears to test Ideal-Free Distribution Models experimentally. Journal of Mammalogy 84:594-606.

Brady, J.R. and D.S. Maehr. 1982. A new method of dealing with apiary-raiding black bears. Proceedings of the Annual Conference of Southeastern Association of Fish and Wildlife Agencies 36:571-577.

Bridges, A.S., C. Olfenbuttel, and M.R. Vaughan. 2002. A mixed regression model to estimate neonatal black bear cub age. Wildlife Society Bulletin 30:1253-1258.

Bunnel, F.L. and D.E.N. Tait. 1977. Bears in models and in reality- implications to management. International Conference of Bear Resource Management 4:15-23.

Calvert R., D. Slate, and P. Debow. 1992. An integrated approach to bear damage management in New Hampshire. Proceedings of the $11^{\text {th }}$ Eastern Black Bear Workshop 11:96-107.

Carr, P.C. and M.R. Pelton. 1984. Proximity of adult female black bears to limited access roads. Proceedings of the Thirty-eighth Annual Conference Southeastern Association of Fish and Wildlife Agencies 38:70-77.

Clark, J.E., F.T. van Manen, and M.R. Pelton. 2002. Correlates of success for on-site releases of nuisance black bears in Great Smokey Mountains National Park. Wildlife Society Bulletin 30:104-111.

Davenport, L.B. 1953. Agricultural depredation by the black bear in Virginia. Journal of Wildlife Management 17:331-340.

Eagle, T. C. and M.R. Pelton. 1983. Seasonal nutrition of black bears in the Great Smokey Mountains National Park. International Conference of Bear Resource Management 5:94-101.

Elowe, K.D. and W.E. Dodge. 1989. Factors affecting black bear reproductive success and cub survival. Journal of Wildlife Management 53:962-968. 
Garshelis, D.L. and M.R. Pelton. 1981. Movements of black bears in the Great Smokey Mountains National Park. Journal of Wildlife Management 45:912-925.

Hellgren, E.C. and D.S. Maehr. 1992. Habitat fragmentation and black bears in the eastern United States. Proceedings of the $11^{\text {th }}$ Eastern Black Bear Workshop 11:154163.

Herrero, S. 1983. Social behavior of black bears at a garbage dump in Jasper National Park. International Conference of Bear Resource Management 5:54-70. , and S. Fleck. 1990. Injury to people inflicted by black, grizzly, and polar bears: recent trends and new insights. International Conference of Bear Resource Management 8:25-32.

, and A. Higgins. 1994. Fatal injuries inflicted to people by black bear. Proceedings of the Fifth Eastern Black Bear Workshop 5:75-81.

Johnson, K.J. and M.R. Pelton. 1980. Prebaiting and snaring techniques for black bears. Wildlife Society Bulletin 8:46-54.

Landers, J.L., R.J. Hamilton, A.S. Johnson, and R.L. Marchinton. 1979. Foods and habitat of black bears in southeastern North Carolina. Journal of Wildlife Management 43:143-153.

Maddrey, R.C. and M. R. Pelton. 1995. Black bear damage to agricultural crops in coastal North Carolina. Proceedings of the Annual Conference of Southeastern Association of Fish and Wildlife Agencies 49:570-579.

Martinka, C.A. 1982. Rationale and options for management of grizzly bear sanctuaries. Transactions of the North American Wildlife and Natural Resources Conference 47:470-475.

Mattson, D.J. 1990. Human impacts on bear habitat use. International Conference of Bear Resource Management 8:33-56. 
Massopust, J.L. and R.K. Anderson. 1984. Homing tendencies of translocated nuisance black bears in northern Wisconsin. Proceedings of the Eastern Workshop on Black Bear Research and Management 7:66-73.

McLean, P.K. and M.R. Pelton. 1989. Some demographic comparisons of wild and panhandler bears in the Smokey Mountains. International Conference of Bear Resource Management 8:105-112.

Pacas, C. J. and P. C. Paquet. 1994. Analysis of black bear home range using a geographic information system. International Conference of Bear Resource Management 9:419-425.

Saunders, D.A., R.J. Hobbs, and C.R. Margules. 1991. Biological consequences of ecosystem fragmentation: a review. Conservation Biology 5:18-32.

SAS. 2000. SAS user's guide: statistics, version 8 edition. SAS Institute, Inc. Cary, North Carolina.

Shull, S.D. 1994. Management of nuisance black bears (Ursus americanus) in the interior highlands of Arkansas. Master's Thesis. University of Arkansas, Fayetteville.

Singer, F.J. and S.P. Bratton. 1980. Black bear-human conflicts in the Great Smokey Mountains National Park. International Conference of Bear Resource Management 4:137-139.

Tate, J. 1985. A profile of panhandling black bears in the Great Smokey Mountains National Park. Doctoral dissertation. University of Tennessee, Knoxville.

U.S. Department of Agriculture (USDA). 2000. Sheep and goats predator loss. National Agricultural Statistics Service. http://jan.mannlib.cornell.edu/reports/nassr/livestock/pct-bbpl/ctpr0501.txt 
_. 2001. U.S. cattle and calves predator loss. National Agricultural Statistics Service. http://jan.mannlib.cornell.edu/reports/nassr/livestock/pgg-bbsg/predan00.txt

U.S. Geological Survey (USGS). 2002. A gap analysis of West Virginia: final report and data. Natural Resources Analysis Center, West Virginia University, Morgantown, West Virginia.

Virginia Department of Game and Inland Fisheries. 2001. Virginia black bear management. Richmond, Virginia.

West Virginia Division of Natural Resources. 2002. West Virginia Big Game Bulletin 03-02, Charleston, West Virginia.

West Virginia Health Statistics Center. 2003. A look at West Virginia's population by decade, 1950-2000, Brief No. 8. http://www.wvdhhr.org/bph/oehp/hsc/briefs/eight/table5.htm

Willey, C.H. 1974. Aging black bears from first premolar tooth sections. Journal of Wildlife Management 38:97-100.

Wooding, J. B., N. L. Hunter, and T. S. Hardisky. 1988. Trap and release apiary-raiding bears. Proceedings of the Annual Conference of Southeastern Association of Fish and Wildlife Agencies 42:333-336. 
Table 1. Number of nuisance and non-nuisance bear captures by sex in southern West Virginia, 1996-2003.

\begin{tabular}{|c|c|c|c|c|}
\hline \multirow[b]{2}{*}{ Year } & \multicolumn{2}{|c|}{ Nuisance } & \multicolumn{2}{|c|}{ Non-Nuisance } \\
\hline & Male & Female & Male & Female \\
\hline 1996 & 3 & 1 & 0 & 0 \\
\hline 1997 & 1 & 4 & 0 & 0 \\
\hline 1998 & 1 & 0 & 0 & 0 \\
\hline 1999 & 20 & 2 & 8 & 8 \\
\hline 2000 & 29 & 5 & 14 & 13 \\
\hline 2001 & 47 & 6 & 7 & 8 \\
\hline 2002 & 26 & 7 & 28 & 32 \\
\hline 2003 & 24 & 3 & 20 & 18 \\
\hline Total & 151 & 28 & 77 & 79 \\
\hline
\end{tabular}


Table 2. Nuisance black bear capture rate and repeat nuisance activity among both sexes by year, southern West Virginia, 1996-2002.

\begin{tabular}{|c|c|c|c|c|c|c|c|c|c|c|c|c|c|c|c|c|c|c|}
\hline \multirow{3}{*}{$\begin{array}{c}\text { Initial } \\
\text { capture } \\
\text { year }\end{array}$} & \multicolumn{18}{|c|}{ Year of repeat nuisance activity $^{\mathrm{a}}$} \\
\hline & \multicolumn{2}{|c|}{ No. } & \multicolumn{2}{|c|}{1996} & \multicolumn{2}{|c|}{1997} & \multicolumn{2}{|c|}{$\underline{1998}$} & \multicolumn{2}{|c|}{1999} & \multicolumn{2}{|c|}{$\underline{2000}$} & \multicolumn{2}{|c|}{$\underline{2001}$} & \multicolumn{2}{|c|}{$\underline{2002}$} & \multicolumn{2}{|c|}{2003} \\
\hline & M & $\mathrm{F}$ & M & $\mathrm{F}$ & M & $\mathrm{F}$ & M & $\mathrm{F}$ & $\mathrm{M}$ & $\mathrm{F}$ & $\mathrm{M}$ & $\mathrm{F}$ & M & $\mathrm{F}$ & $\mathrm{M}$ & $\mathrm{F}$ & $\mathrm{M}$ & $\mathrm{F}$ \\
\hline 1996 & 3 & 1 & 0 & 0 & 0 & 1 & 0 & 0 & 1 & 0 & 0 & 0 & 2 & 0 & 0 & 0 & 0 & 0 \\
\hline 1997 & 1 & 4 & & & 0 & 0 & 0 & 1 & 1 & 0 & 0 & 0 & 0 & 0 & 0 & 0 & 0 & 0 \\
\hline 1998 & 1 & 0 & & & & & 0 & 0 & 0 & 0 & 0 & 0 & 0 & 0 & 0 & 0 & 0 & 0 \\
\hline 1999 & 20 & 2 & & & & & & & 4 & 0 & 9 & 0 & 0 & 0 & 1 & 0 & 1 & 0 \\
\hline 2000 & 29 & 5 & & & & & & & & & 2 & 0 & 5 & 0 & 2 & 0 & 2 & 0 \\
\hline 2001 & 47 & 6 & & & & & & & & & & & 3 & 0 & 8 & 0 & 8 & 0 \\
\hline 2002 & 26 & 7 & & & & & & & & & & & & & 3 & 0 & 3 & 0 \\
\hline 2003 & 24 & 3 & & & & & & & & & & & & & & & 12 & 1 \\
\hline
\end{tabular}

${ }^{a}$ Repeat nuisance activity was counted once per individual per year, but any one individual may be represented across multiple years. 
29 Nov 2004

James T. Anderson

Division of Forestry

West Virginia University

P.O. Box 6125

322 Percival Hall

Morgantown, WV 26506

304-293-2941 x 2445; FAX 304-293-2441; jander25@wvu.edu

RH: Black Bear Weight Estimation `Weaver et al.

\section{Estimating nuisance and non-nuisance black bear weights using chest-girth circumference $^{\mathrm{A}-}$}

Harley W. Weaver, West Virginia University, Division of Forestry, P.O. Box 6125, Morgantown, WV 26506, USA, Evolven@aol.com

James T. Anderson, West Virginia University, Division of Forestry, P.O. Box 6125

Morgantown, WV 26506, USA

John W. Edwards, West Virginia University, Division of Forestry, P.O. Box 6125

Morgantown, WV 26506, USA

Thomas L. Dotson, West Virginia Division of Natural Resources, Route 1 Box 484, Point Pleasant, WV 25550-9734, USA

Abstract: Body weight among ursids help serve as an index of habitat quality, health, and reproductive potential. However, due to their large size, weighing black bears (Ursus americanus) in the field can be a cumbersome and sometimes impractical task. This problem created a need for predictive equations that require simple measures to approximate weight. We calculated the relation of chest-girth circumference with weight $\left(r^{2}=0.92\right)$ among 335 black bears from southern West Virginia. Male and female bears involved in nuisance activities and animals not known to exhibit such behavior varied in their chest-girth circumference. Unlike previous studies, we report separate predictive

A- This Chapter was written in the style of the Wildlife Society Bulletin. 
equations regarding weight based on girth for both sex and behavior type; nuisance males

$[$ Weight $=-150.382+(2.546 \times$ girth $)]$, nuisance females $[$ Weight $=-49.446+(1.350 \times$ girth)], non-nuisance males [Weight $=-102.225+(2.020 \times$ girth $)]$, and non-nuisance females $[$ Weight $=-073.297+(1.644 \times$ girth $)]$. Between behavior types, nuisance bears weighed more and had a higher weight/girth ratio than non-nuisance bears. Additional predictive equations were developed for both sex and behavior type using age to model gains in weight, girth, and the weight/girth ratio based on sex, age, and behavior. As age increased for male and female bears, weight, girth, and the weight/girth ratio increased as a quadratic function. Researchers may benefit from more accurate weight estimators for black bears by recognizing variability among gender and behavior types.

Wildlife Society Bulletin 00(0):000-000

Key Words: age, behavior, black bear, chest-girth, non-nuisance, nuisance, Ursus americanus, weight, weight/girth ratio, West Virginia

Growth rates among black bears can serve as an index of habitat quality and health. Such biological factors may influence weight, in turn, affecting the reproductive potential of the species (Elowe and Dodge 1989, McLean and Pelton 1990, Stringham 1990, Beckmann and Berger 2003). To provide researchers with intelligible data, measures of weight must be obtained from study animals. However, due to their large size, adult black bears are difficult to weigh in the field. By developing predictive equations using chest-girth circumference, researchers can employ an effective and efficient method for estimating weight.

Significant correlations between chest-girth circumference and weight have been reported for polar bears (U. maritimus) (Kolenosky et al. 1989), grizzly bears (U. arctos) 
(Nagy et al. 1984), and black bears (Payne 1976, Alt 1980). Previous studies correlating black bear weight and chest-girth circumference pooled male and female data to develop predictive equations (Payne 1976, Alt 1980). However, we believe data pooled across genders may conceal weight and chest-girth variability and should be tested.

Bears are an opportunistic species that will supplement their natural diet with high quality human-related foods (Herrero 1983, McLean and Pelton 1990) including refuse and agricultural crops (Mattson 1990, Calvert et al. 1992, Meadows 1998), particularly during poor mast years (Eagle and Pelton 1983, McLean and Pelton 1989, Igo 2001). Such foraging behavior has led refuse foraging animals to gain more weight than similar aged black bears not routinely consuming refuse (Rogers et al. 1976, Tate 1985, Rogers 1987, McLean and Pelton 1990, Beckmann and Berger 2003). We defined individuals who demonstrated unwanted destructive behavior such as raiding apiaries and bird feeders, or most commonly consuming garbage as nuisance bears. Non-nuisance bears were defined as individuals not known to alter their natural diet by consuming humanrelated foods. Based on studies by McLean and Pelton (1990) and Beckmann and Berger (2003), we hypothesized that data pooled across nuisance and non-nuisance bears may provide inaccurate equations due to variation in body mass. The objectives of our study were to develop predictive equations estimating weight from chest-girth circumference and model growth rates between genders and behavior types (i.e., nuisance, nonnuisance).

\section{Study Area}

Our study was conducted in 4 southern West Virginia counties (Kanawha, Fayette, Raleigh, and Boone) located between Charleston and Beckley, West Virginia. Topography was steep, with elevation ranging from 173 to 1,063 meters. Major cover types on the study area included mixed-mesophytic hardwood forest, cove hardwood 
forest, and oak (Quercus spp.) dominated forest (United States Geological Survey 2002). Coal extraction has heavily influenced this region, including deep mining, mountain top removal mining, and valley fill practices. Collectively, 352,407 people lived in the 4 counties, which was $19.5 \%$ of the total West Virginia population in 2000 (West Virginia Health Statistics Center 2003). Kanawha County, the most urbanized county within the study area, had the largest human population of the 55 counties in the state. Minimum population estimates indicated that black bear numbers nearly quadrupled within a 10year period, 1989-1998 (Table 1), increasing at an average annual rate of $16.9 \%$ from 182 animals to 699 animals within the 4 counties (J. E. Evans, West Virginia Division of Natural Resources, unpublished data).

\section{Methods}

After a nuisance complaint, West Virginia Division of Natural Resources (WVDNR) personnel used baited culvert traps to capture offending bears. Generally, culvert traps were set within 24-48 hours after receiving the complaint. Nuisance bears were captured from early April until mid to late August. Non-nuisance black bears were captured from June until August using modified Aldrich type foot snares in forested habitats (Johnson and Pelton 1980).

WVDNR personnel immobilized captured individuals with Telazol (1:1 mixture of tiletamine hydrochloride and zolazepam hydrochloride; Elkins-Sinn, Inc., Cherry Hill, N.J.) at a rate of $5.0 \mathrm{mg} / \mathrm{kg}$ of body weight and recorded physical characteristics such as sex, weight, and chest-girth (Weaver et al. 2003). Girth was measured directly behind the front legs using a fabric tape measure and recorded to the nearest centimeter during chest exhalation. WVDNR biologists removed one upper premolar from each individual to estimate age via cementum annuli counts (Willey 1974). Matson's Laboratory (Milltown, MT) sectioned and aged all teeth. 
We used three-factor analysis of variance (ANOVA; PROC GLM; SAS 2000) and contrasts to make pair-wise comparisons (CONTRAST; PROC GLM; SAS 2000) for weight and chest-girth (dependent variables) among sex, age, and behavior (nuisance and non-nuisance) groups (independent variables).

Data were separated into spring (April through June), or summer (July through August) depending on date of capture. Analysis of the data set (PROC UNIVARIATE; SAS 2000) indicated a normal distribution. However, when we used the whole model (including season, sex, age, and type), we could only look at 2-way interactions due to degree of freedom limitations. We determined sex and age were significant as main or interaction effects $(P<0.05)$. To simplify the model, we sought to remove season, type, or both. When season was removed, type became significant in relation to mass and the weight/girth ratio $(P<0.05)$. When type was removed, season was non-significant for all 3 variables $(P>0.05)$. Accordingly, season was the only variable removed from the model. Using a reduced model (sex, age, and type) allowed a 3-way interaction and all 2way interactions. To develop predictive equations, we fit one model to each data set predicting weight, girth, and the weight/girth ratio with age. Therefore, each model was represented by 1 sample size and $r^{2}$ value, from which individual equations were derived for sex and behavior types.

Predicted weights from regression analysis of weight on girth included all bears. Contrasts following regression analysis compared weight and girth between genders and behavior types (nuisance and non-nuisance). We developed predictive equations using a regression model with sex and behavior type as categorical variables and age as a continuous variable (Proc GLM; SAS 2000). A significance level of $\underline{\alpha}=0.05$ was used for all statistical tests. 


\section{Results}

WVDNR captured 335 bears (179 nuisance, 156 non-nuisance) from 1996-2003. However, sample sizes for analysis were lower due to missing or incomplete weight, age, or girth data. There were 322 bears captured during spring and summer. Due to nonsignificant differences, weight $\left(F_{1,171}=0.67, P=0.413\right)$ and girth $\left(F_{1,99}=0.05, P=\right.$ $0.819)$ measurements were pooled across spring $(n=84)$ and summer $(n=184)$. Bear ages ranged from 1 to 14 years, and no cubs ( $<1$ year old) were represented in this data set.

In the full model, girth was a good predictor of weight $\left(r^{2}=0.92\right)$ for both sex and behavior type. A 3-way interaction existed among girth $\times \operatorname{sex} \times$ type $\left(F_{1,176}=3.99, P=\right.$ 0.047), therefore separate girth to mass equations were developed for each combination of gender and behavior type. Individual girth to weight predictive equations were developed for nuisance males, non-nuisance males, nuisance females, and non-nuisance females (Table 2).

Weight was greater for males than females $\left(F_{1,176}=85.28, P \leq 0.001\right)$ and greater for nuisance than non-nuisance bears $\left(F_{1,176}=12.22, P \leq 0.001\right.$; Table 3$)$. There were no sex $\times$ age $\times$ type $\left(F_{5,176}=0.73, P=0.604\right)$, age $\times$ type $\left(F_{7,176}=0.56, P=0.790\right)$, or sex $\times$ type $\left(F_{1,176}=0.23, P=0.632\right)$ interactions for weight. However, a 2-way interaction existed for sex $\times$ age $\left(F_{9,176}=2.93, P=0.003\right)$. Therefore, differences in weights were tested between sexes for each age separately (Table 4).

Girth was greater for males than for females $\left(F_{1,106}=26.99, P \leq 0.001\right)$, but was similar between behavior types $\left(F_{1,106}=2.49, P=0.118\right.$; Table 3$)$. There was no sex $\times$ age $\times$ type $\left(F_{2,106}=0.80, P=0.452\right)$, age $\times$ type $\left(F_{7,106}=0.77, P=0.614\right)$, sex $\times$ type $\left(F_{1,106}=0.38, P=0.537\right)$, or sex $\times$ age $\left(F_{6,106}=1.46, P=0.198\right)$ interactions for girth. 
Weight/girth ratio was greater for males than females $\left(F_{1,100}=22.08, P \leq 0.001\right)$ and was greater for nuisance than for non-nuisance bears $\left(F_{1,100}=4.57, P=0.035\right.$; Table 3). There were no sex $\times$ age $\times$ type $\left(F_{1,100}=1.55, P=0.215\right)$, age $\times$ type $\left(F_{6,100}=0.08\right.$, $P=0.998)$, sex $\times$ type $\left(F_{1,100}=0.05, P=0.827\right)$, or sex $\times$ age $\left(F_{6,100}=0.95, P=0.462\right)$ interactions.

As age increased in male $(n=147)$ and female $(n=66)$ bears, weight increased $\left(F_{1,205}=5.94, P=0.016\right)$ as a quadratic function (Fig. 1$)$. Nuisance bears were heavier than non-nuisance bears of the same age $\left(F_{1,205}=11.83, P \leq 0.001\right)$. From regression analysis $\left(r^{2}=0.70\right)$, predictive equations were derived for gender and behavior type (Table 5). Regardless of behavior type, predictive equations indicated the age of maximum weight for male (10.4 years) and female (10.7 years) bears. Predictive modeling from regression analysis indicated weight gains declined between successive age cohorts from youngest to oldest $\left(F_{1,205}=5.94, P=0.016\right)$ in both male and female bears (Fig. 2).

With increasing age among male $(n=87)$ and female $(n=51)$ bears, girth increased $\left(F_{1,133}=12.01, P<0.001\right)$ as a quadratic function (Fig. 1). From regression analysis $\left(r^{2}=0.56\right)$, we developed predictive equations for male and female bears (Table 5). Predictive equations estimated the age of maximum girth for males (12.6 years) and females (9.1 years). Predictive modeling from regression analysis indicated gains in girth declined between successive age cohorts from youngest to oldest $\left(F_{1,133}=12.01, P \leq\right.$ 0.001) among all bears (Fig. 2).

As age increased in male $(n=79)$ and female $(n=49)$ bears, weight/girth ratio increased $\left(F_{1,122}=25.55, P<0.001\right)$ as a quadratic function (Fig. 1). Nuisance bears had a larger weight/chest girth ratio than non-nuisance bears of the same age $\left(F_{1,122}=6.54, P\right.$ $=0.012$ ). From regression analysis $\left(r^{2}=0.57\right)$, predictive equations were developed for 
gender and behavior type (Table 5). Regardless of sex or behavior type, predictive equations indicated the age of the maximum weight/girth ratio to be 9.2 years. Predictive modeling from regression analysis indicated weight/girth ratio gains declined between successive age cohorts from youngest to oldest $\left(F_{1,122}=25.55, P \leq 0.001\right)$ among all bears (Fig. 2).

\section{Discussion}

Chest girth was a good predictor of weight for both sexes and behavior types. Unlike previous girth to weight correlations from Pennsylvania (Alt 1980) and Newfoundland (Payne 1976) where all black bear measures were pooled, we segregated values between gender and behavior types. In doing so, we believe more appropriate estimates of mass were obtained.

Males were heavier than females and nuisance bears were heavier than individuals not demonstrating nuisance behavior. Bears that routinely consumed high calorie foods such as human refuse were likely to acquire more mass than non-nuisance individuals (Rogers et al. 1976, Tate 1985, Rogers 1989, McLean and Pelton 1990, Beckmann and Berger 2003).

Measured against the same chest-girth circumference, weight was significantly different between gender and behavior groups. Male weight/girth ratio was greater than female bears. A greater amount of muscle mass in males, rather than less dense fatty tissues, may contribute to weight/girth variation. Similar results in sexual dimorphism have been reported for reptiles (Bonnet et al. 1998), birds (Badyaev et al. 2001), and other mammals (Schulte-Hostedde et al. 2001). Overall, nuisance bears had a higher weight/girth ratio than non-nuisance bears. An increase in the weight/girth ratio may highlight differences in certain growth and nutrition variables. Perhaps nuisance bears are attaining more dense muscle mass through increased protein loading, increased bone 
density from mineral rich refuse, or from increased fat reserves stored in areas not affecting chest circumference. Although uncertain at this point, a combination of factors may affect the growth and development of refuse feeding bears.

Based on predictive equations derived from regression analysis, nuisance male weight, girth, and the weight/girth ratio was greater than similar aged bears from all other groups ranging from age 1 to 14 years. These physical measures declined in value across all years corresponding to sex (greater values for males) and behavior type (greater values for nuisance bears); non-nuisance males, nuisance females, and non-nuisance females. Alt (1980) reported similar trends in weight and chest girth between male and female bears although maximum age was 8 years old.

The estimated age of maximum weight occurred for both male and female bears between 10 and 11 years of age. Estimates of weight decreased from ages 11 to 14 years, perhaps indicative of deteriorating health problems in older bears. However, samples sizes also were reduced in the older age classes, which may have affected results. Such age related diseases are common in carnivorous mammal species and lead to reduced fitness (Aiello 1998).

Growth trends in girth varied by gender, but not behavior type. Predictive equations estimated the age of maximum girth for males (12-13 years) was about 3 years more than females (9-10 years). Increasing girth in males, 2 years beyond the predicted age for maximum weight, likely indicates increasing fat deposition rather than further muscle development. Female girth peaked 1 year prior to their estimated maximum weight, indicating further fat reserves may have been collected in areas not affecting chest girth. Regardless of sex or behavior type, the age when the maximum weight/girth ratio occurred for all bears was between 9 and 10 years, indicating the greatest weight 
potential for bears of a given chest girth. In promoting this idea, this age would likely be the point animals are retaining the greatest amount of dense muscle tissue.

Mean weight, girth, and weight/girth ratio among each age class were greater than the previous cohort until the maximum age indicated by each predictive equation. However, between all groups, gains in weight, girth, and the weight/girth ratio declined during each successive year from youngest to oldest. Measures of growth follow a similar trend reported in Pennsylvania’s black bear population (Alt 1980).

\section{Management Implications}

Due to their large size, weighing black bears in the field can be a cumbersome and sometimes impractical task. Such constraints require the development of predictive equations to estimate weight using simple technique such as measuring chest-girth circumference. There have been efforts elsewhere to provide reliable methods to approximate weight. However, we recognize sex and behavior type as factors that influence weight and girth variability among black bears. By recognizing this variability, managers may benefit from more accurate estimates of weight. By providing predictive equations for black bear weight estimation and expected growth rates, we anticipate their use at both the individual and population level.

\section{Acknowledgments}

We thank the West Virginia Division of Natural Resources, the Northeast Wildlife Damage Management Cooperative, and the West Virginia University Davis College of Agriculture, Forestry, and Consumer Sciences (McIntire-Stennis) for funding this research. We thank the numerous West Virginia Division of Natural Resources personnel including G. Sharp, S. Houchins, E. Richmond, D. Arbogast, A. Worley, C. Lawson, R. Pettrey, J. Craft, E. Holland, R. Roles, L. Berry, J. Hajenga, C. Carpenter, and E. Thorn for trapping and handling bears. In particular, we thank J. Evans, P. 
Johansen, and C. Ryan for their support of this project. Statistical assistance provided by G. Seidel is also greatly appreciated. This is manuscript number 0000 of the West Virginia University Agricultural and Forestry Experiment Station.

\section{Literature cited}

Aiello, S. E. 1998. The Merck Veterinary Manual. Eighth edition. Merck \& Company, Inc., Whitehouse Station, New Jersey, USA.

Alt, G. L. 1980. Rate of growth and size of Pennsylvania black bears. Pennsylvania Game News 51:7-17.

Badyaev, A. V., L. A. Whittingham, and G. E. Hill. 2001. The evolution of sexual size dimorphism in the house finch. III. Developmental basis. Evolution 55:176-189.

Beckmann, J. P., and J. Berger. 2003. Using black bears to test ideal-free distribution models experimentally. Journal of Mammalogy 84:594-606.

Bonnet, X., R. Shine, G. Naulleau, and M. Vacher-Vallas. 1998. Sexual dimorphism in snakes: different reproductive roles favor different body plans. Proceedings of The Royal Society: Biological Sciences 265:179-183.

Calvert R., D. Slate, and P. Debow. 1992. An integrated approach to bear damage management in New Hampshire. Proceedings of the $11^{\text {th }}$ Eastern Black Bear Workshop 11:96-107.

Eagle, T. C., and M. R. Pelton. 1983. Seasonal nutrition of black bears in the Great Smokey Mountains National Park. International Conference on Bear Research and Management 5:94-101.

Elowe, K. D., and W.E. Dodge. 1989. Factors affecting black bear reproductive success and cub survival. Journal of Wildlife Management 53:962-968.

Herrero, S. 1983. Social behavior of black bears at a garbage dump in Jasper National Park. International Conference on Bear Research and Management 5:54-70. 
Igo, W. K. 2001. West Virginia Status Report. Eastern Workshop on Black Bear Resources and Management 16:88-98.

Johnson, K. J., and M. R. Pelton. 1980. Prebaiting and snaring techniques for black bears. Wildlife Society Bulletin 8:46-54.

Kolenosky, G. B., Lunn, N. J., Greenwood, C. J., and Abraham, K. F. 1989. Estimating the weight of polar bears from body measurements. Journal of Wildlife Management 53:188-190.

Mattson, D. J. 1990. Human impacts on bear habitat use. International Conference on Bear Research and Management 8:33-56.

Meadows, L. E., Andelt, W. F. and T. I. Beck. 1998. Managing bear damage to beehives. Colorado State University Cooperative Extension Report No. 6519.

McLean, P. K., and M. R. Pelton. 1989. Some demographic comparisons of wild and panhandler bears in the Smokey Mountains. International Conference on Bear Research and Management 8:105-112.

Nagy, J. A., M. C. Kingsley, R. H. Russel, M. Pearson, and B. C. Goski. 1984. Relationship of weight to chest girth in the grizzly bear. Journal of Wildlife Management 48:1439-1440.

Payne, N. F. 1976. Estimating live weight of black bears from chest girth measurements. Journal of Wildlife Management 40:167-169.

Rogers, L. L., D. W. Kuehn, A. W. Erickson, E. M. Harger, L. J. Verme, and J. J Ozoga. 1976. Characteristics and management of black bears that feed in garbage dumps, campgrounds or residential areas. International Conference on Bear Research and Management 3:169-175.

Rogers, L. L. 1987. Black bears, people, and garbage dumps in Minnesota. Bear-people conflicts: Pages 43-46 in Proceedings of a Symposium on Management 
Strategies (1989). Northwest Territories Department of Renewable Resources, 6 April-10 April 1987, Yellowknife, Northwest Territories, Canada.

Rogers, L. L., 1989. Black bears, people and garbage dumps in Minnesota. Pages 43-46 in M. Bromley, edition, Bear-people conflicts: proceedings of a symposium on management strategies. Northwest Territories Department of Natural Resources, Yellowknife, NWT.

SAS. 2000. SAS user's guide: statistics, version 8 edition. SAS Institute, Inc. Cary, North Carolina.

Schulte-Hostedde, A. I., J. S. Millar, and G. J. Hickling. 2001. Sexual dimorphism in body composition of small mammals. Canadian Journal of Zoology 79:10161020.

Stringham, S. F. 1990. Black bear reproductive rate relative to body weight in hunted populations. International Conference on Bear Research and Management 8:425432.

Tate, J. 1985. A profile of panhandling black bears in the Great Smokey Mountains National Park. Dissertation, University of Tennessee, Knoxville, Tennessee, USA.

U.S. Geological Survey (USGS). 2002. A gap analysis of West Virginia: final report and data. Natural Resources Analysis Center, West Virginia University, Morgantown, West Virginia, USA.

Weaver, H. W., J. T. Anderson, J. W. Edwards, and T. L. Dotson. 2003. Physical and behavioral characteristics of nuisance and non-nuisance black bears in southern West Virginia. Proceedings of the Southeastern Association of Fish and Wildlife Agencies 57:in press. 
West Virginia Health Statistics Center. 2003. A look at West Virginia's population by decade, 1950-2000, Brief No. 8. http://www.wvdhhr.org/bph/oehp/hsc/briefs/eight/table5.htm

Willey, C. H. 1974. Aging black bears from first premolar tooth sections. Journal of Wildlife Management 38:97-10. 
Table 1. Black bear population estimates from Kanawha, Fayette, Raleigh, and Boone Counties in southern West Virginia from 1989-1998 (J. Evans, West Virginia Division of Natural Resources, Elkins, West Virginia, unpublished data).

\begin{tabular}{lrrrrrrrrrr}
\hline Year & 1989 & 1990 & 1991 & 1992 & 1993 & 1994 & 1995 & 1996 & 1997 & 1998 \\
\hline Males & 63 & 69 & 110 & 147 & 184 & 194 & 214 & 243 & 262 & 339 \\
Females & 119 & 111 & 153 & 190 & 217 & 290 & 312 & 350 & 343 & 360 \\
Total & 182 & 180 & 263 & 337 & 401 & 484 & 526 & 593 & 605 & 699 \\
\hline
\end{tabular}


Table 2. Predictive equations estimating weight $(\mathrm{kg})$ from the measure of chest-girth circumference (cm) for black bears in southern West Virginia, 1996-2003.

\begin{tabular}{|c|c|c|c|c|}
\hline Gender & Behavior type & $n$ & $r^{2}$ & Predictive equation \\
\hline \multirow[t]{2}{*}{ Male } & Nuisance & 59 & 0.94 & Weight $=-150.382+(2.546 \times$ girth $)$ \\
\hline & Non-nuisance & 55 & 0.97 & Weight $=-102.225+(2.020 \times$ girth $)$ \\
\hline \multirow[t]{2}{*}{ Female } & Nuisance & 9 & 0.89 & Weight $=-49.446+(1.350 \times$ girth $)$ \\
\hline & Non-nuisance & 61 & 0.89 & Weight $=-73.297+(1.644 \times$ girth $)$ \\
\hline
\end{tabular}


Table 3. Age adjusted summary of weight, girth, and weight/girth measurements by gender and behavior type for black bears in southern West Virginia, 1996-2003.

\begin{tabular}{|c|c|c|c|c|c|c|c|c|c|}
\hline & \multicolumn{3}{|c|}{ Weight $(\mathrm{kg})$} & \multicolumn{3}{|c|}{ Girth $(\mathrm{cm})$} & \multicolumn{3}{|c|}{ Weight/Girth $(\mathrm{kg} / \mathrm{cm})$} \\
\hline & $n$ & $\bar{x}$ & SD & $n$ & $\bar{x}$ & $\mathrm{SD}$ & $n$ & $\bar{x}$ & $\mathrm{SD}$ \\
\hline \multicolumn{10}{|l|}{ MALES } \\
\hline Nuisance & 100 & 104.9 & 40.5 & 45 & 103.9 & 15.0 & 40 & 1.0 & 0.3 \\
\hline $\begin{array}{l}\text { Non- } \\
\text { nuisance }\end{array}$ & 47 & 76.6 & 32.5 & 42 & 88.9 & 14.7 & 39 & 0.8 & 0.2 \\
\hline All males & 147 & 95.8 & 40.2 & 87 & 96.6 & 16.5 & 79 & 0.9 & 0.2 \\
\hline \multicolumn{10}{|l|}{ FEMALES } \\
\hline Nuisance & 16 & 71.8 & 22.0 & 8 & 87.4 & 6.9 & 7 & 0.8 & 0.1 \\
\hline $\begin{array}{l}\text { Non- } \\
\text { nuisance }\end{array}$ & 50 & 61.2 & 14.5 & 43 & 82.9 & 8.9 & 42 & 0.7 & 0.1 \\
\hline All females & 66 & 63.8 & 17.1 & 51 & 83.6 & 8.7 & 49 & 0.7 & 0.1 \\
\hline \multicolumn{10}{|l|}{ COMBINED } \\
\hline Nuisance & 116 & 100.4 & 40.1 & 53 & 101.3 & 15.3 & 47 & 1.0 & 0.2 \\
\hline Non-nuisance & 97 & 68.6 & 25.9 & 85 & 85.9 & 12.4 & 81 & 0.8 & 0.2 \\
\hline
\end{tabular}


Table 4. Differentiation of weights $(\mathrm{kg})$ tested among age and gender for black bears in southern West Virginia, 1996-2003.

\begin{tabular}{|c|c|c|c|c|c|c|c|}
\hline \multirow[b]{3}{*}{ Age } & \multicolumn{6}{|c|}{ Weight (kg) } & \multirow[b]{3}{*}{$P$-value } \\
\hline & \multicolumn{2}{|c|}{ Males } & & \multicolumn{3}{|c|}{ Females } & \\
\hline & $n$ & $\bar{x}$ & SE & $n$ & $\bar{x}$ & $\mathrm{SE}$ & \\
\hline 1 & 43 & 59.4 & 3.7 & 9 & 46.4 & 5.1 & 0.196 \\
\hline 2 & 28 & 77.0 & 4.4 & 11 & 53.9 & 4.5 & 0.055 \\
\hline 3 & 21 & 99.2 & 5.8 & 10 & 55.0 & 2.5 & 0.002 \\
\hline 4 & 17 & 120.1 & 6.4 & 5 & 67.7 & 4.7 & $\leq 0.001$ \\
\hline 5 & 18 & 129.6 & 6.0 & 8 & 68.8 & 2.0 & $\leq 0.001$ \\
\hline 6 & 5 & 136.2 & 19.3 & 9 & 72.2 & 5.5 & $\leq 0.001$ \\
\hline 7 & 9 & 141.5 & 5.7 & 6 & 79.8 & 6.6 & 0.007 \\
\hline 8 & 2 & 153.2 & 19.3 & 3 & 76.9 & 7.1 & $\leq 0.001$ \\
\hline 9 & 2 & 158.9 & 4.5 & 1 & 67.2 & -- & $\leq 0.001$ \\
\hline
\end{tabular}


Table 5. Predictive equations estimating weight $(\mathrm{kg})$, girth $(\mathrm{cm})$, and the weight $/ \mathrm{girth}(\mathrm{kg} / \mathrm{cm})$ ratio based upon the age of black bears in southern West Virginia, 1996-2003.

\begin{tabular}{lcccc}
\hline & $n$ & $r^{2}$ & Males & Females \\
\hline Weight (kg) & & & & \\
Nuisance & & & $43.576+(23.218 \times \mathrm{Age})-\left(1.114 \times \mathrm{Age}^{2}\right)$ & $0.732+(0.116 \times \mathrm{Age})-\left(0.0063 \times \mathrm{Age}^{2}\right)$ \\
Non-nuisance & 184 & 0.70 & & \\
Girth (cm) & & & $28.109+(23.218 \times \mathrm{Age})-\left(1.114 \times \mathrm{Age}^{2}\right)$ & $0.603+(0.116 \times \mathrm{Age})-\left(0.0063 \times \mathrm{Age}^{2}\right)$ \\
All Bears & 138 & 0.56 & $75.833+(08.028 \times \mathrm{Age})-\left(0.319 \times \mathrm{Age}^{2}\right)$ & $65.951+(05.839 \times \mathrm{Age})-\left(0.319 \times \mathrm{Age}^{2}\right)$ \\
Ratio (kg/cm) & & & & \\
Nuisance & & & $44.967+(08.078 \times \mathrm{Age})-\left(0.375 \times \mathrm{Age}^{2}\right)$ & $0.447+(0.116 \times \mathrm{Age})-\left(0.0063 \times \mathrm{Age}^{2}\right)$ \\
& 128 & 0.57 & & \\
Non-nuisance & & & $35.982+(08.078 \times \mathrm{Age})-\left(0.375 \times \mathrm{Age}^{2}\right)$ & $0.393+(0.116 \times \mathrm{Age})-\left(0.0063 \times \mathrm{Age}^{2}\right)$ \\
\hline
\end{tabular}




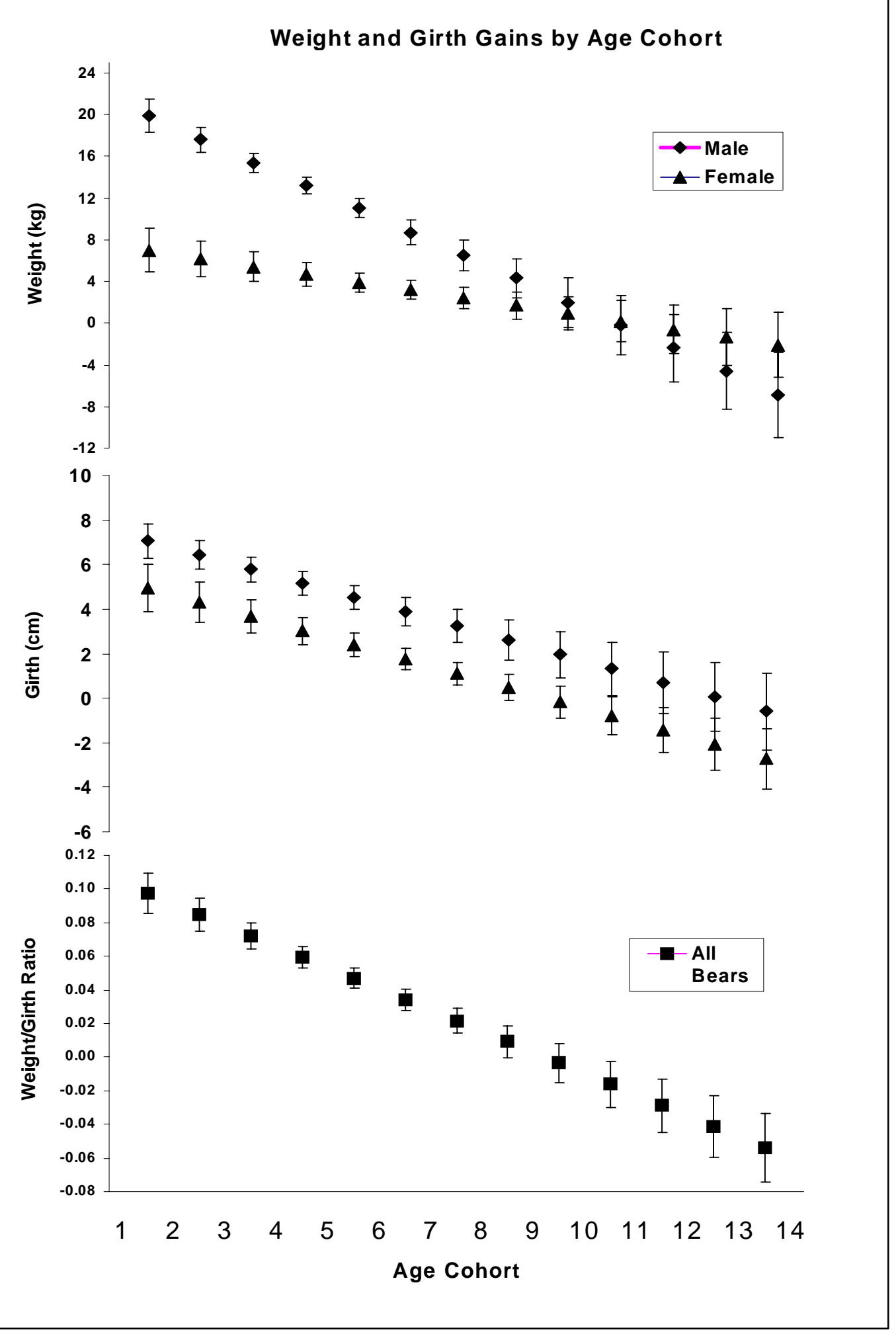

Figure 1. Predictive growth rates (SE bars) based on age cohorts for southern West Virginia black bears by gender and behavior type, 1996-2003; weight $(n=213)$, girth $(n=138)$, and weight/girth ratio $(n=128)$. 


\section{Growth Among Sex and Behavior Type}
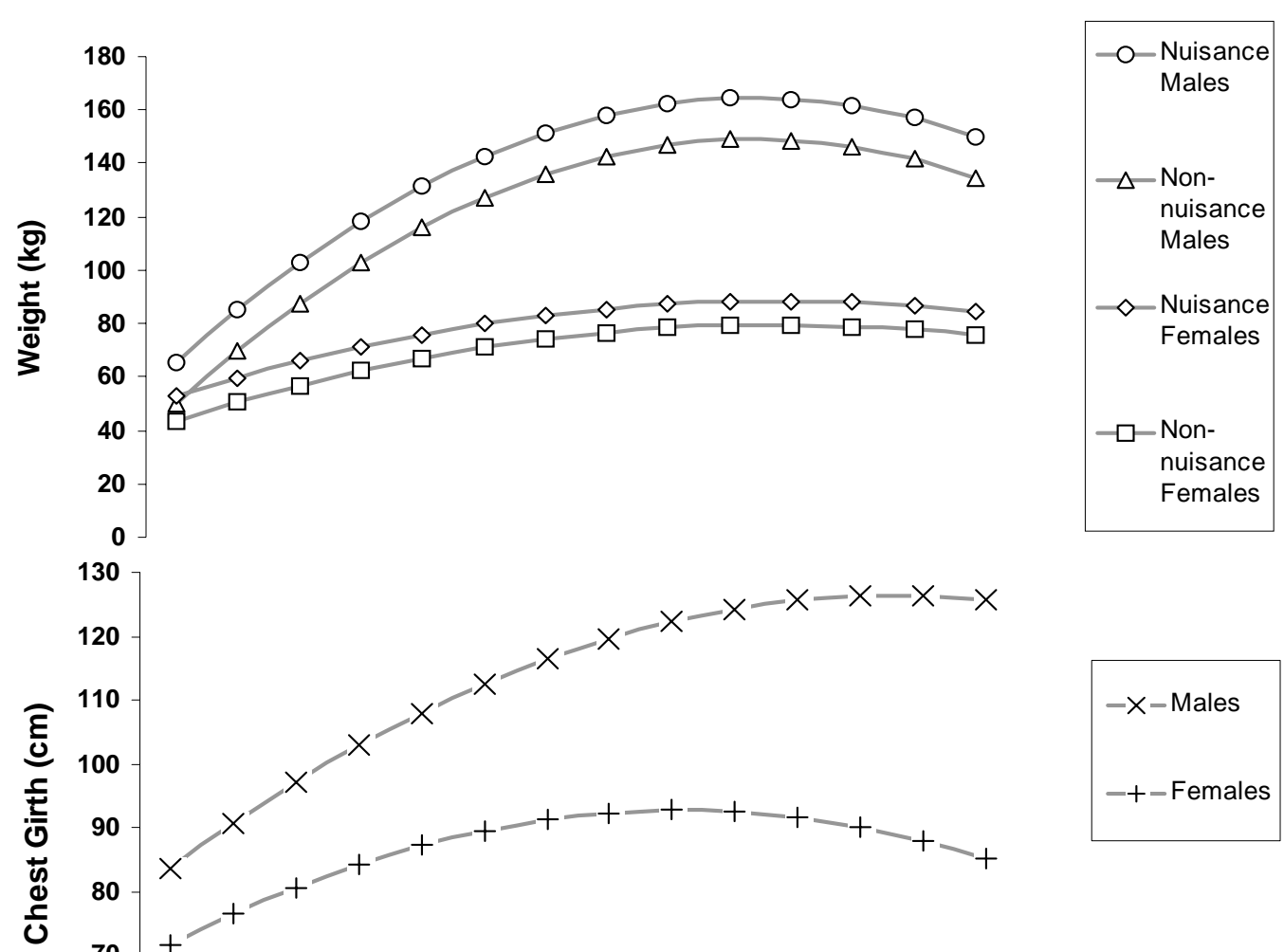

U
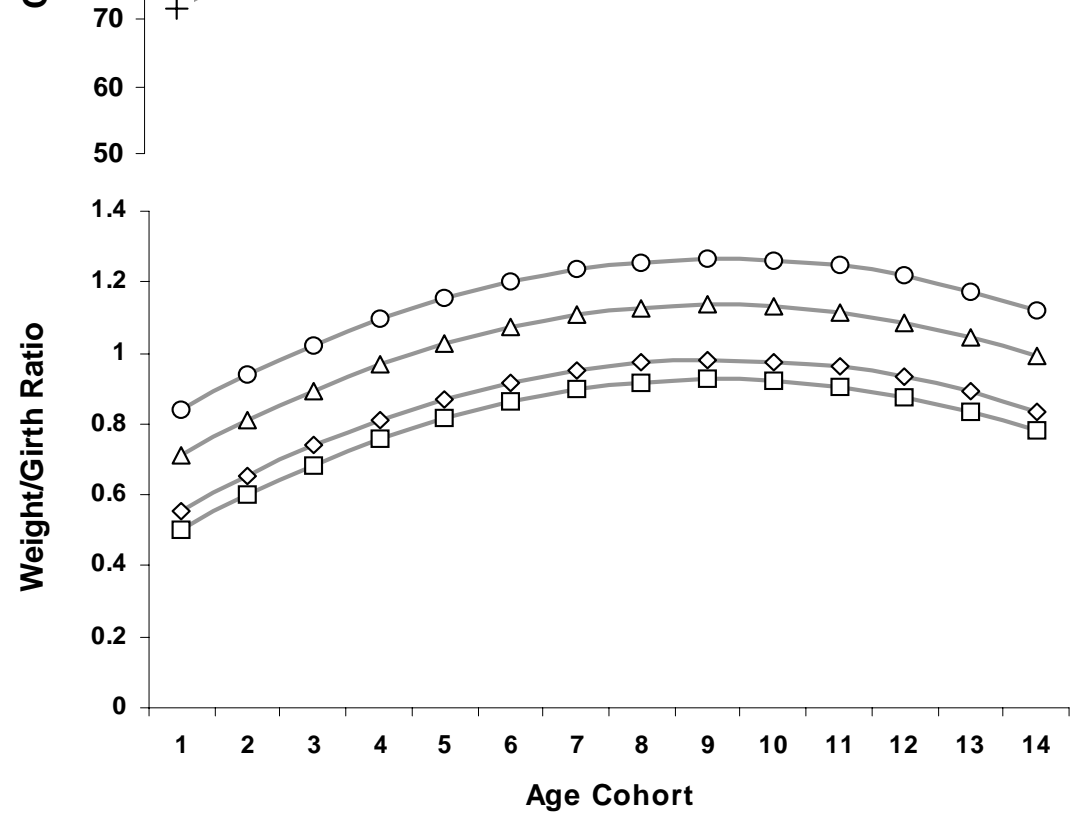

Figure 2. Predicted gains in weight and girth among age cohorts for black bears in southern West Virginia, 1996-2003. 